\title{
BIOREMEDIATION OF PETROLEUM HYDROCARBON CONTAMINATED SITES
}

\section{TOPICAL REPORT}

Start Date: 2001

End Date: 2007

By

Paul Fallgren

April 2009

Work Performed Under Cooperative Agreement

JSR Task 25 DE-FC26-98FT40323

For

TechLink Environmental, Inc.

Fort Collins, Colorado

And

U.S. Department of Energy

National Energy Technology Laboratory

Morgantown, West Virginia

By

Western Research Institute

Laramie, Wyoming

Kamal Das

Task 25 


\section{TABLE OF CONTENTS}

Page

LIST OF TABLES AND FIGURES...................................................................... iii

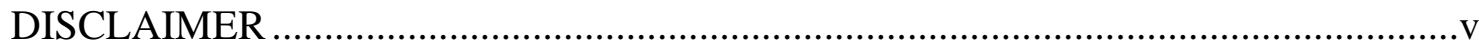

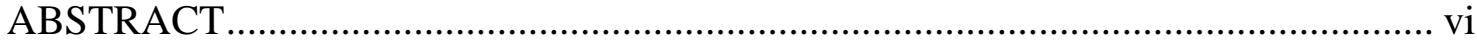

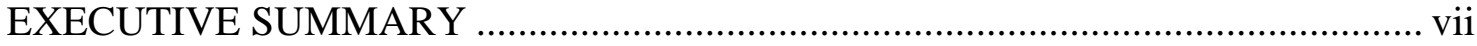

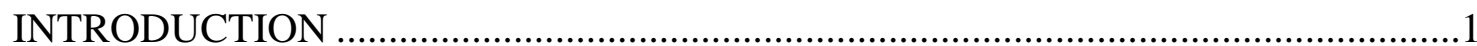

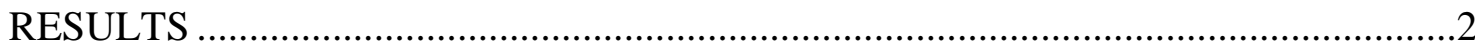

Soil Physical Characteristics ...........................................................................2

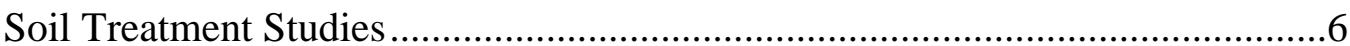

Biotreatment Cell (Biocell) Studies .................................................................13

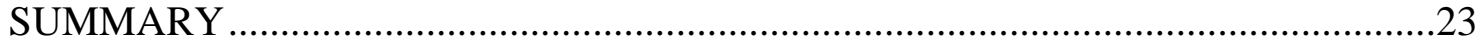

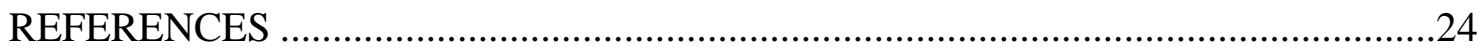

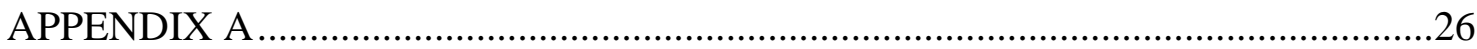

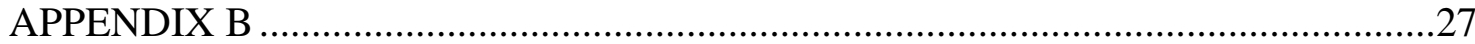




\section{LIST OF TABLES AND FIGURES}

Table

Page

1 Mass Relationships of Plot \#4 Soils Exposed to Air-Dry and Oven-Dry

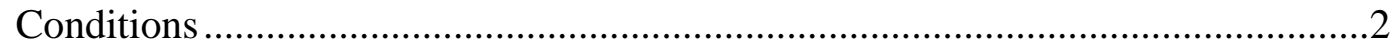

2 Percent Organic Matter Determined By LOI and Toluene Extraction on Fine-Earth and Coarse Fragment Fractions of Plot \#4 Soil ......................................3

3 Percent Sand, Silt, Clay, and Rock for Plot \#4 Soils ................................................

4 Mean Hydraulic Conductivity for Core \#1 and Core \#2 Prepared From

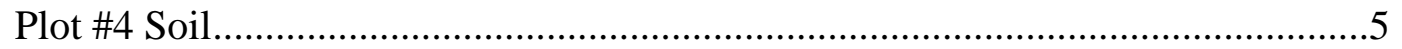

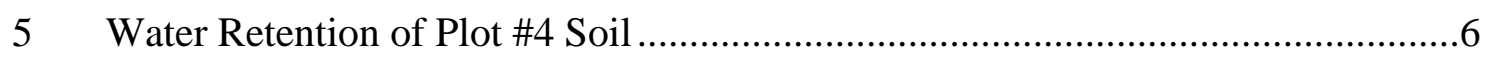

$\begin{array}{ll}\text { Figure } & \text { Page }\end{array}$

1 Microbial $\mathrm{CO}_{2}$ Production From Biodegradation of Hydrocarbons in Soil

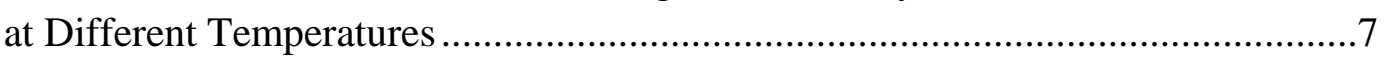

2 Microbial $\mathrm{CO}_{2}$ Production From Biodegradation of Hydrocarbons in Soil at

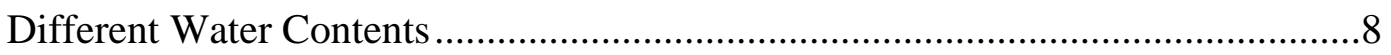

3 Microbial $\mathrm{CO}_{2}$ Production From Biodegradation of Hydrocarbons in Soil Amended With Artificial Seawater at Different $\mathrm{NaCl}$ Concentrations (a) and Different Multiples of the Seawater Constituents (b) ...............................................

4 Microbial $\mathrm{CO}_{2}$ Production From Biodegradation of Hydrocarbons in Soil at

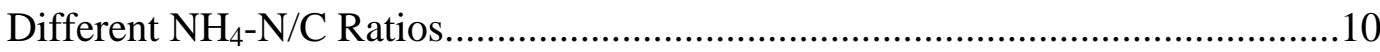

5 Microbial $\mathrm{CO}_{2}$ Production From Biodegradation of Hydrocarbons in Soil at Different $\mathrm{NO}_{3}-\mathrm{N} / \mathrm{C}$ Ratios..............................................................................

6 Microbial $\mathrm{CO}_{2}$ Production From Biodegradation of Hydrocarbons in Soil at Different P/C Ratios.......................................................................................

$7 \quad$ Urea Amendments in Biodegradation (Microbial Respiration)..............................12

8 Amounts of Urea Amendments in Biodegradation (TPH Degradation)..................13

$9 \quad$ Photograph of the "Mini-Biocell” System I Setup …………….............................14

10 Photograph of the Bench-Scale Biocell (System II) .............................................14

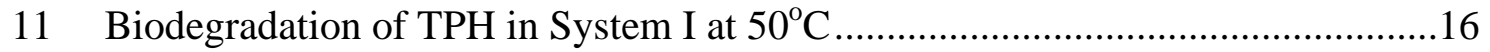

12 Cumulative $\mathrm{CO}_{2}$ Production in System I at $50^{\circ} \mathrm{C}$.................................................16

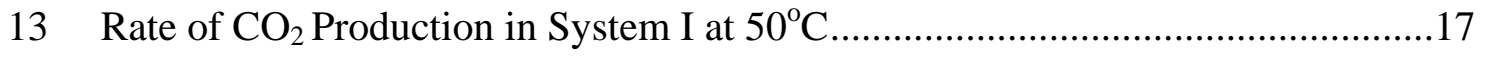




\section{LIST OF FIGURES (CONT’D)}

Figure $\quad$ Page

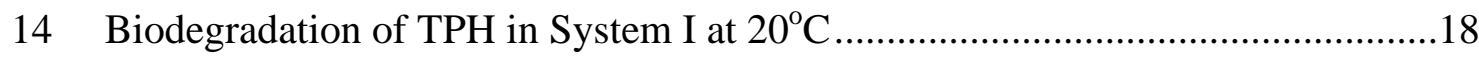

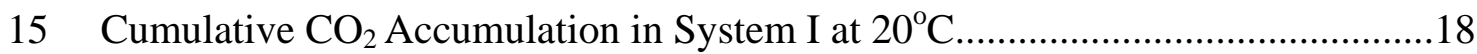

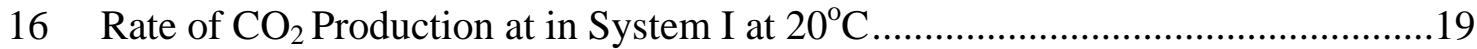

17 Biodegradation of TPH in System I With Temperature Adjustment....................20

$18 \mathrm{CO}_{2}$ Accumulation in System I With Temperature Adjustment .........................20

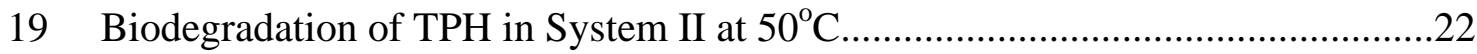

20 Side View of a Design for a Field-Scale Biocell .............................................23 


\section{DISCLAIMER}

This report was prepared as an account of work sponsored by an agency of the United States Government. Neither the United States Government nor any agency thereof, nor any of their employees makes any warranty, express or implied, or assumes any legal liability or responsibility for the accuracy, completeness, or usefulness of any information, apparatus, product, or process disclosed or represents that its use would not infringe on privately owned rights. Reference herein to any specific commercial product, process, or service by trade name, trademark, manufacturer, or otherwise does not necessarily constitute or imply endorsement, recommendation, or favoring by the United States Government or any agency thereof. The views and opinions of authors expressed herein do not necessarily state or reflect those of the United States Government or any agency thereof. 


\begin{abstract}
Bioremediation has been widely applied in the restoration of petroleum hydrocarboncontaminated. Parameters that may affect the rate and efficiency of biodegradation include temperature, moisture, salinity, nutrient availability, microbial species, and type and concentration of contaminants. Other factors can also affect the success of the bioremediation treatment of contaminants, such as climatic conditions, soil type, soil permeability, contaminant distribution and concentration, and drainage. Western Research Institute in conjunction with TechLink Environmental, Inc. and the U.S. Department of Energy conducted laboratory studies to evaluate major parameters that contribute to the bioremediation of petroleum-contaminated drill cuttings using land farming and to develop a biotreatment cell to expedite biodegradation of hydrocarbons. Physical characteristics such as soil texture, hydraulic conductivity, and water retention were determined for the petroleum hydrocarbon contaminated soil. Soil texture was determined to be loamy sand to sand, and high hydraulic conductivity and low water retention was observed. Temperature appeared to have the greatest influence on biodegradation rates where high temperatures $\left(>50^{\circ} \mathrm{C}\right)$ favored biodegradation. High nitrogen content in the form of ammonium enhanced biodegradation as well did the presence of water near field water holding capacity. Urea was not a good source of nitrogen and has detrimental effects for bioremediation for this site soil. Artificial sea water had little effect on biodegradation rates, but biodegradation rates decreased after increasing the concentrations of salts. Biotreatment cell (biocell) tests demonstrated hydrocarbon biodegradation can be enhanced substantially when utilizing a leachate recirculation design where a $72 \%$ reduction of hydrocarbon concentration was observed with a 72-h period at a treatment temperature of $50^{\circ} \mathrm{C}$. Overall, this study demonstrates the investigation of the effects of environmental parameters on bioremediation is important in designing a bioremediation system to reduce petroleum hydrocarbon concentrations in impacted soils.
\end{abstract}




\section{EXECUTIVE SUMMARY}

Bioremediation exploits the ability of certain microorganisms, usually heterotrophic bacteria and fungi, to degrade organic materials to innocuous materials such as carbon dioxide, methane, water, inorganic salts, and biomass. Microorganisms may derive the carbon and energy required for growth through the biodegradation of organic contaminants or transforms more complex organics through fortuitous cometabolism. Bioremediation has been widely applied in the restoration of petroleum hydrocarbon-contaminated soils. Petroleum hydrocarbons in excess of 20,000 ppm can be tolerated without inhibition to microbial growth. The complexity of the bioremediation process can be great at many sites due to large number of interacting factors that impact the microbial populations and their abilities to degrade the contaminants present. This complexity has shown the remediation industry the need to carry out detailed laboratory testing before the biological process can be successfully applied in the field. Effort in the laboratory most often translates into successful field applications of bioremediation technology.

Contaminated sites are complex in nature, and often several techniques are required for complete remediation. A range of factors is known to influence the biological transformation and degradation of contaminants. Parameters that may affect the rate and efficiency of biodegradation include temperature, moisture, salinity, nutrient availability, microbial species, and type and concentration of contaminants. Other factors can also affect the success of the bioremediation treatment of contaminants, such as climatic conditions, soil type, soil permeability, contaminant distribution and concentration, and drainage.

Western Research Institute in conjunction with TechLink Environmental, Inc. and the U.S. Department of Energy conducted laboratory studies to evaluate major parameters that contribute to the bioremediation of petroleum-contaminated drill cuttings using land farming and to develop a biotreatment cell to expedite biodegradation of hydrocarbons. The materials used in this investigation were collected from petroleum-impacted sites in east Egypt (Ras Shukheir facility). The results and conclusions of these studies are summarized as follows:

- Physical characteristics such as soil texture, hydraulic conductivity, and water retention were determined for the petroleum hydrocarbon contaminated soil from a site in Egypt. These physical characteristics are important design parameters for bioremediation since they influence the availability of water to microorganisms. Three PSA methods were used to determine soil texture which was determined to be loamy sand to sand. The high hydraulic conductivity and low water retention observed for the contaminated soil are due to the combination of the soil texture and the hydrophobic organic material (i.e., hydrocarbons) adsorbed to the soil particles. The adsorbed hydrocarbons repel water which increases hydraulic conductivity and lowers water retention. 
- The effects of environmental parameters such as temperature, water content, salinity, and nutrient contents were investigated using respirometry. Temperature appeared to have the greatest influence on biodegradation rates where high temperatures $\left(>50^{\circ} \mathrm{C}\right)$ favored biodegradation. This is due to a possible abundance of thermophilic bacteria that may exist in soil where surface temperatures are high. High nitrogen content in the form of ammonium enhanced biodegradation as well did the presence of water near field water holding capacity. Urea was not a good source of nitrogen and has detrimental effects for bioremediation for this site soil. Artificial sea water had little effect on biodegradation rates, but biodegradation rates decreased after increasing the concentrations of salts.

- Biotreatment cell (biocell) tests demonstrated hydrocarbon biodegradation can be enhanced substantially when utilizing a leachate recirculation design. Due to the water repulsion (high hydraulic conductivity), nutrients and water treatments infiltrate to the bottom of the biocell. The recirculation of the leachate increases bioavailability and further enhances biodegradation of hydrocarbons in the soil. A $72 \%$ reduction of hydrocarbon concentration was observed with a 72-h period at a treatment temperature of $50^{\circ} \mathrm{C}$.

Overall, this study demonstrates the investigation of the effects of environmental parameters on bioremediation is important in designing a bioremediation system to reduce petroleum hydrocarbon concentrations in impacted soils. 


\section{INTRODUCTION}

Petroleum exploration, transport, refining, and storage activities generate large amounts of wastes that have adverse impacts on soil and groundwater quality. Bioremediation exploits the ability of certain microorganisms, usually heterotrophic bacteria and fungi, to degrade organic materials to innocuous materials such as carbon dioxide, methane, water, inorganic salts, and biomass. Microorganisms may derive the carbon and energy required for growth through the biodegradation of organic contaminants or transforms more complex organics through fortuitous cometabolism. Fortuitous cometabolism is synonymous with the microbial metabolism of contaminants that are not growth substrates (Anderson, 1995). Bioremediation has been widely applied in the restoration of petroleum hydrocarbon-contaminated sites (Atlas, 1991; Bento et al., 2005; Piskonen et al., 2002). It is known that hydrocarbons and weathered oils with carbon contents of about $20 \%$ degrade slowly (Flathman et al., 1993). However, petroleum hydrocarbons in excess of 20,000 ppm can be tolerated without inhibition to microbial growth (Kaufman, 1993). Efforts continue to improve the rates of degradation of these types of materials.

The complexity of the bioremediation process can be great at many sites due to large number of interacting factors that impact the microbial populations and their abilities to degrade the contaminants present (King et al., 1997; ASTM, 1998). This complexity has shown the remediation industry the need to carry out detailed laboratory testing before the biological process can be successfully applied in the field (Deull et al., 1997). Laboratory treatability studies generate useful information for the design of full-scale systems and may be used to develop new processes or specific bacteria cultures that can be taken to the field. Effort in the laboratory most often translates into successful field applications of bioremediation technology (Anderson, 1996; EPA, 1995; Hinchee, 1995).

Contaminated sites are complex in nature, and often several techniques are required for complete remediation. A range of factors is known to influence the biological transformation and degradation of contaminants. Parameters that may affect the rate and efficiency of biodegradation include temperature, moisture, salinity, nutrient availability, microbial species, and type and concentration of contaminants (Head and Swannell, 1999; Alexander, 1998; Sikdar, 1998; Zhou and Crawford, 1995). Nutrient availability, such as nitrogen and phosphorus, is often limited in petroleum-contaminated soils due to the excessive carbon input from the hydrocarbons. Therefore, nitrogen and phosphorus are usually identified as the limiting factors for biodegradation in soils (Brook et al., 2001; Walworth and Reynolds, 1995). Other factors can also affect the success of the bioremediation treatment of contaminants, such as climatic conditions, soil type, soil permeability, contaminant distribution and concentration, and drainage. 
As noted previously, the natural rate of microbial biodegradation of the petroleum hydrocarbons is usually constrained by limiting factors. A variety of environmental factors may be rate limiting in the microbial degradation of petroleum hydrocarbons. It is critical to identify and remove these rate-limiting factors for successful bioremediation of contaminated material. Western Research Institute (WRI) in conjunction with TechLink Environmental, Inc. and the U.S. Department of Energy (DoE) conducted laboratory studies to evaluate major parameters that contribute to the bioremediation of petroleum-contaminated drill cuttings using land farming. The materials used in this investigation were collected from petroleum-impacted sites in east Egypt (Ras Shukheir facility). The investigations lead to the development of a benchscale biotreatment cell (solid-phase bioreactor) which then led to the design of a field-scale system.

\section{RESULTS}

\section{Soil Physical Characteristics}

Air-dry and Oven-dry Mass Determination

Approximately $18.5 \mathrm{~kg}$ of soil was taken from the cold storage container labeled Plot \#4, spread out and allowed to dry. Twelve sub-samples $(\sim 100 \mathrm{~g})$ were rapidly placed in drying containers and the mass recorded. Three of the samples were oven-dried at $105^{\circ} \mathrm{C}$. The mass of the samples exposed to ambient laboratory conditions was monitored daily for a period of 318 hours, and the mass of oven-dried samples was monitored periodically for 72 hours (Table 1).

Table 1.Mass Relationships of Plot \#4 Soils Exposed to Air-Dry and Oven-Dry Conditions.

\begin{tabular}{|l|c|c|c|}
\hline Drying Condition & n & $\begin{array}{c}\text { Mean Mass Lost } \\
(\mathbf{\%})\end{array}$ & Std. Deviation \\
\hline Air-dry (318 hrs) & 9 & 0.99 & 0.09 \\
\hline Oven-dry (72 hrs) & 3 & 4.1 & 0.31 \\
\hline
\end{tabular}

\section{Particle Size Analysis}

Particle size analysis was completed for seven samples using the hydrometer method described by Gee and Bauder (1986). Samples that contain high levels of organic constituents require pretreatment to reduce interference of these materials with the mineral fraction of the sample. The standard method described by Gee and Bauder (1986) for removal of organic material is treatment of the sample with $\mathrm{H}_{2} \mathrm{O}_{2}$ and refluxing at $90^{\circ} \mathrm{C}$ until all of the organic material is oxidized. 
Approximately $500 \mathrm{~g}$ of sample was passed through a 2-mm sieve and the mass of both fractions was recorded. The fine-earth fraction $(<2 \mathrm{~mm})$ was subdivided into three samples that were treated by the peroxide method. Samples were maintained in a water bath $\left(90^{\circ} \mathrm{C}\right)$ and $\mathrm{H}_{2} \mathrm{O}_{2}$ was applied in $10 \mathrm{~mL}$ aliquots every 30 to $60 \mathrm{~min}$ for approximately 12 hours. At the end of the initial treatment period, substantial oily residue remained on the liquid surface of the samples, while the settled mineral fraction appeared to be detached from the organic fraction. The oily residue was skimmed from the liquid surface. Samples were treated with additional $\mathrm{H}_{2} \mathrm{O}_{2}$ for approximately 6 hours. The liquid surface was again skimmed at the end of this period to remove remaining organic material. After skimming the samples were placed in an oven at $105^{\circ} \mathrm{C}$ and dried for 24 hours.

We hypothesized that physical removal of organic residue from these samples would bias the mechanical analysis because colloidal minerals were attached to the organic fraction. Therefore, two alternative methods (loss on ignition and toluene extraction) were used to remove the organic fraction from the samples. In addition, the total petroleum hydrocarbon (TPH) fraction of an additional sample was analyzed by hexane extraction according to EPA methods.

A total of 5 samples were passed through a 2-mm sieve and the mass of each fraction was determined. Total organic carbon (TOC) was determined for the fine-earth fraction of 2 fineearth samples and the coarse-fragment fraction of 4 samples by loss on ignition (LOI) using a muffle furnace at $450^{\circ} \mathrm{C}$. The total extractable organic carbon (TEC) was determined as mass lost by toluene extraction for two of the fine-earth samples. Similarly, TPH was analyzed, with duplication, by hexane extraction for the remaining fine-earth sample. Results from the three analyses are presented in Table 2.

Table 2. Percent Organic Matter Determined by LOI and Toluene Extraction on FineEarth and Coarse Fragment Fractions of Plot \#4 Soil.

\begin{tabular}{|l|c|c|c|}
\hline Sample & Fraction & Treatment & TOC \% \\
\hline$\# 1-1$ & $<2 \mathrm{~mm}$ & LOI & 10.3 \\
\hline$\# 1-2$ & $<2 \mathrm{~mm}$ & LOI & 9.4 \\
\hline$\# 1-1$ & $>2 \mathrm{~mm}$ & LOI & 4.6 \\
\hline$\# 1-2$ & $>2 \mathrm{~mm}$ & LOI & 4.2 \\
\hline$\# 2-1$ & $>2 \mathrm{~mm}$ & LOI & 7.0 \\
\hline$\# 2-2$ & $>2 \mathrm{~mm}$ & LOI & 3.4 \\
\hline & & & TEC \% \\
\hline$\# 2-1$ & $<2 \mathrm{~mm}$ & Toluene & 7.5 \\
\hline$\# 2-2$ & $<2 \mathrm{~mm}$ & Toluene & 7.9 \\
\hline & & & TPH \% \\
\hline$\# 3-1$ & $<2 \mathrm{~mm}$ & Hexane & 3.6 \\
\hline$\# 3-1$ dup & $<2 \mathrm{~mm}$ & Hexane & 3.3 \\
\hline
\end{tabular}


Subsequent to treatment, all treated samples were dispersed and particle size distribution was determined using the hydrometer method. Sample suspensions were passed through a .0.05$\mathrm{mm}$ sieve and the retained fraction was oven-dried and weighed to determine mass percentage of the sand fraction. The percent distribution of particle sizes in the fine-earth fraction representing sand $(0.05$ to $2.0 \mathrm{~mm})$, silt $(0.002$ to $0.05 \mathrm{~mm})$, and clay $(<0.002 \mathrm{~mm})$ and USDA textural classification was determined for each sample (Table 3 ).

Table 3.Percent Sand, Silt, Clay, and Rock for Plot \#4 Soils

\begin{tabular}{|l|c|c|c|c|c|c|c|}
\hline Sample & Extraction & Sand \% & Silt \% & Clay \% & $\begin{array}{c}\text { Rock } \\
\text { \% }\end{array}$ & Texture & $\begin{array}{c}\text { Sieve } \\
\text { Sand \% }\end{array}$ \\
\hline$\# 1-1$ & LOI & 88.8 & 1.9 & 9.4 & 41 & LS/S & 89.7 \\
\hline$\# 1-2$ & LOI & 88.8 & 1.9 & 9.4 & 37 & LS/S & 89.8 \\
\hline$\# 2-1$ & Toluene & 88.8 & 3.4 & 7.8 & 39 & S & 88.9 \\
\hline$\# 2-2$ & Toluene & 88.8 & 3.4 & 7.8 & 41 & S & NA \\
\hline$\# 3-1$ & Peroxide & 92.5 & 3.0 & 4.5 & 42 & S & 91.8 \\
\hline$\# 3-2$ & Peroxide & 92.6 & 3.0 & 4.4 & 42 & S & 92.0 \\
\hline$\# 3-3$ & Peroxide & 92.5 & 3.0 & 4.5 & 42 & S & 92.5 \\
\hline
\end{tabular}

\section{Hydraulic Conductivity}

Saturated hydraulic was measured using a constant head permeameter. Two cores were prepared using air-dry sample. A total of 1,314-g of bulk soil (fine-earth and rock) was packed into the specimen tube of the permeameter $\left(920 \mathrm{~cm}^{3}\right)$. Preliminary data indicated that $2 \%$ of the sample mass would be lost during oven drying. Therefore, the mass indicated above packed into the specimen tube yielded a core bulk density of $1.4 \mathrm{~g} \mathrm{~cm}^{-3}$. Core \#1 was saturated (submerged) with de-aired tap water for 24 hours before test initiation. After saturation, the reservoir tube of the permeameter was filled with deaired tap water and the test was initiated. The test was replicated four times using the same core. The core was allowed to remain submerged for approximately 60 hours, over the weekend, between replications 2 and 3 . The core was removed and mass water content was determined by drying in an oven at $105^{\circ} \mathrm{C}$ for 48 hours.

A second core was prepared using the same specifications as Core \#1; however, all four test replications were completed on the same day. A bubble trapped on top of the specimen was noted after the first test. The bubble was removed and tests were continued. The core was removed and dried as indicated for core \#1. The mean hydraulic conductivity was calculated using readings from 10 min until the termination of the test for each replication (Table 4). 
Table 4. Mean Hydraulic Conductivity for Core \#1 and Core \#2 Prepared From Plot \#4 Soil

\begin{tabular}{|c|c|c|c|}
\hline Sample & Replication & Mean K $\left(\mathrm{cm} \mathrm{s}^{-1}\right)$ & Mean K $\left(\mathrm{M} \mathrm{dy}^{-1}\right)$ \\
\hline Core \#1 & 1 & 1.90E-01 & 164 \\
\hline Core \#1 & 2 & $1.80 \mathrm{E}-01$ & 156 \\
\hline Core \#1 & 3 & $1.61 \mathrm{E}-01$ & 139 \\
\hline Core \#1 & 4 & $1.54 \mathrm{E}-01$ & 133 \\
\hline Core \#2 & 1 & 1.89E-01 & 163 \\
\hline Core \#2 & 2 & 2.83E-01 & 245 \\
\hline Core \#2 & 3 & $1.96 \mathrm{E}-01$ & 169 \\
\hline Core \#2 & 4 & 1.61E-01 & 139 \\
\hline \multicolumn{2}{|c|}{ Mean Hydraulic Conductivity: } & 1.89E-01 & 164 \\
\hline
\end{tabular}

The volumetric water content for each core was determined from the mass wetness and bulk density of the cores and the degree of saturation was calculated. The degree of saturation was $60 \%$ for core \# 1 and $53 \%$ for core \#2. The unexpectedly low saturation levels occurred because of rapid drainage of water from the cores during the disassembly of the permeameter which resulted in lower gravimetric water content. Given the hydrophobic nature of these materials, the level of achievable saturation was unknown. Consequently, saturation tests were conducted using four, 2-cm x 1-cm soil retainer rings packed to a bulk density of $1.4 \mathrm{~g}$. The rings were placed on a ceramic water retention plate covered with deaired tap water at a level just below the height of the cores, covered, and allowed to soak overnight. The cores were removed from the plate and placed in an oven at $105^{\circ} \mathrm{C}$ for 24 -hr. Mass wetness was determined from wet and oven-dry mass. Volumetric water content and degree of saturation were calculated from mass wetness and bulk density. The mean degree of saturation for the samples was $108 \%$ with a standard deviation of $\pm 3 \%$. The high degree of saturation is acceptable since slight swelling of the cores was noted during the saturation process. Swelling can occur from repulsive forces associated with the hydrophobic nature of these materials.

\section{Water Retention}

The relation between soil water content and matric potential is a fundamental intrinsic soil property. A low- range pressure plate system was used to determine "field capacity" moisture contents. The first test was conducted using soil retainer rings (vol) packed with soil (< $2 \mathrm{~mm}$ ) to a bulk density of $1.4 \mathrm{~g} \mathrm{~cm}^{-3}$. Twelve packed rings were placed on a 1 bar ceramic plate immersed in deaired tap water, covered, and allowed to soak for 24-hr. Excess water was removed from the ceramic plate. The plate was placed in a sealed pressure chamber, and 1 bar cell pressure was applied to system for $24.5-\mathrm{hr}$ and the test was terminated. The samples were rapidly removed from the ceramic plate and oven-dried to determine mass wetness (Table 5). 
This initial test (\#1) was completed without covering samples while inside of the pressure chamber which can an underestimate of water retention because of evaporative losses. Therefore, the test is being repeated using the same cell pressure with samples covered to minimize evaporative losses.

Water retention was also completed at 0.33 bar and 5.0 bar cell pressures to develop a low-range soil moisture retention function. However, the results from the higher cell pressures show no difference in water content from the 0.1 bar pressure. An important consideration when reviewing these data is the mass of hydrocarbon that is lost as a result of oven-drying. The data from the air-dry and oven-dry mass determination section of this document show that $3.1 \%$ of the sample mass lost between air-dry and oven-dry conditions. The data from other noncontaminated coarse-textured soils show that an average of $1.3 \%$ of sample mass is lost between oven-dry and air-dry conditions. Therefore, the additional $1.8 \%$ of mass lost with the contaminated, Egypt soils must be related to hydrocarbon volatilization. Consequently, $1.8 \%$ should be subtracted from the mass wetness values reported in Table 5 to provide a more accurate estimation of the percentage of water that is retained by these materials.

Table 5. Water Retention of Plot \#4 Soil

\begin{tabular}{|l|c|c|c|c|c|}
\hline Sample Set & $\mathbf{n}$ & $\begin{array}{c}\text { Pressure } \\
\text { (bar) }\end{array}$ & $\begin{array}{c}\text { Mass Wetness } \\
\mathbf{( \% )}\end{array}$ & $\begin{array}{c}\text { Volumetric Water } \\
\text { Content (\%) }\end{array}$ & $\begin{array}{c}\text { Saturation } \\
\mathbf{( \% )}\end{array}$ \\
\hline$\# 1$ not covered & 12 & 0.10 & 12.9 & 18.1 & 38.3 \\
\hline$\# 2$ & 12 & 0.10 & 12.6 & 17.6 & 37.3 \\
\hline$\# 3$ & 12 & 0.33 & 12.5 & 17.5 & 37.1 \\
\hline$\# 4$ & 12 & 5.00 & 12.2 & 17.1 & 36.3 \\
\hline
\end{tabular}

\section{Soil Treatment Studies}

Bench-top respirometry is an effective method of measuring microbial respiration, i.e. $\mathrm{CO}_{2}$ production and $\mathrm{O}_{2}$ consumption. Respirometry is advantageous in monitoring biodegradation that would be otherwise difficult to quantify. This method allows for easy control of parameters important to biodegradation (e.g., $\mathrm{N}$ content), and determination of kinetics from the rate of $\mathrm{CO}_{2}$ release from the soil. It can also help determine phases of biodegradation such as adaptation and active biodegradation. Carbon dioxide produced from microbial degrading activity and evolving from soil was measured using a Columbus Instruments MicroOxymax respirometer (Columbus, $\mathrm{OH}$; picture in Appendix A) equipped with a $\mathrm{CO}_{2}$ sensor. Each parameter tested involved microcosms (100-ml screw-top jars) containing $20 \mathrm{~g}$ of the contaminated soil and corresponding treatments. The parameter tested (e.g., temperature, moisture) was varied while other supporting parameters were held constant. Each treatment was duplicated. 
The microbial respiration rates were monitored when samples were incubated in the temperature range of $4.0^{\circ} \mathrm{C}-92^{\circ} \mathrm{C}$. In the soil samples, the active temperature range for normal microbial activities was observed at $20^{\circ} \mathrm{C}-82^{\circ} \mathrm{C}$, with the highest $\mathrm{CO}_{2}$ production rate occurring at $80^{\circ} \mathrm{C}$ (Figure 1). When temperature was below $20^{\circ} \mathrm{C}$ or above $82^{\circ} \mathrm{C}$, microbial respiration declined substantially. The data indicate that the dominant microbial population in the contaminated soil is hyperthermophilic, with an optimal temperature at $80^{\circ} \mathrm{C}$. This may be attributed to the microbial adaptation to the warm, arid climate at the sampling site.

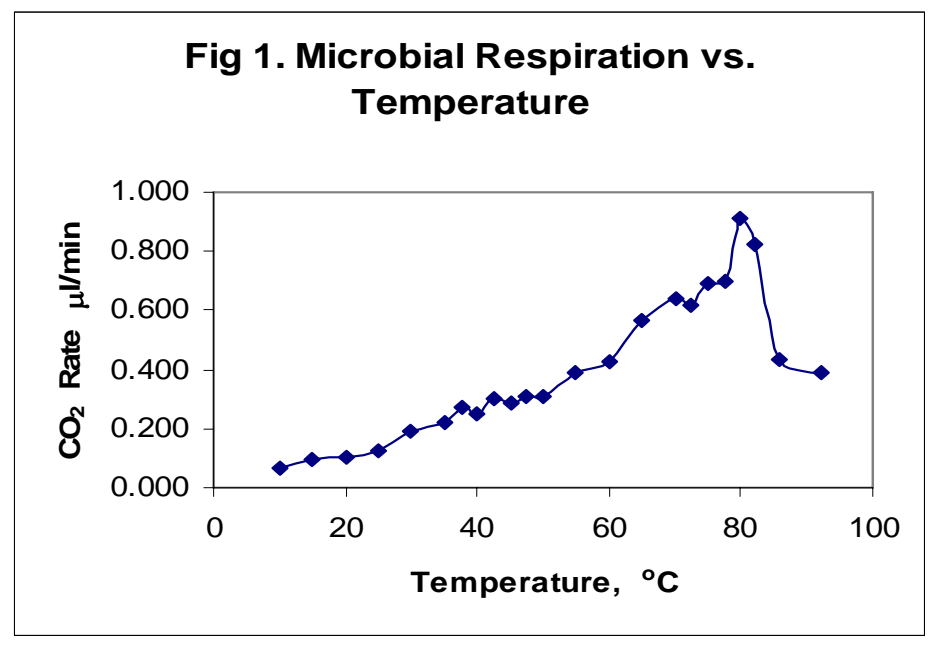

\section{Figure 1.Microbial $\mathrm{CO}_{2}$ Production From Biodegradation of Hydrocarbons in Soil at Different Temperatures}

\section{Effects of Soil Water Content and Salinity}

Microbial respiration showed a parallel trend with increasing moisture contents, until the field water holding capacity of $10 \%$ was approximately reached (Figure 2). At water content above $7 \%$, microbial respiration rates stabilized with no further increase. Due to the sandy texture, field water holding capacity the soil is relatively low. Indigenous microorganisms have adapted to the arid environment during the long term exposure to the petroleum contamination in the desert. Consequently optimal microbial activities may be achieved rapidly and maintained at relative low water content. Microbial respiration rate rose from $0.025 \mu \mathrm{l} / \mathrm{min}$ to $0.25 \mu \mathrm{l} / \mathrm{min}$ at a water concentration of $7 \%$ (by weight). 


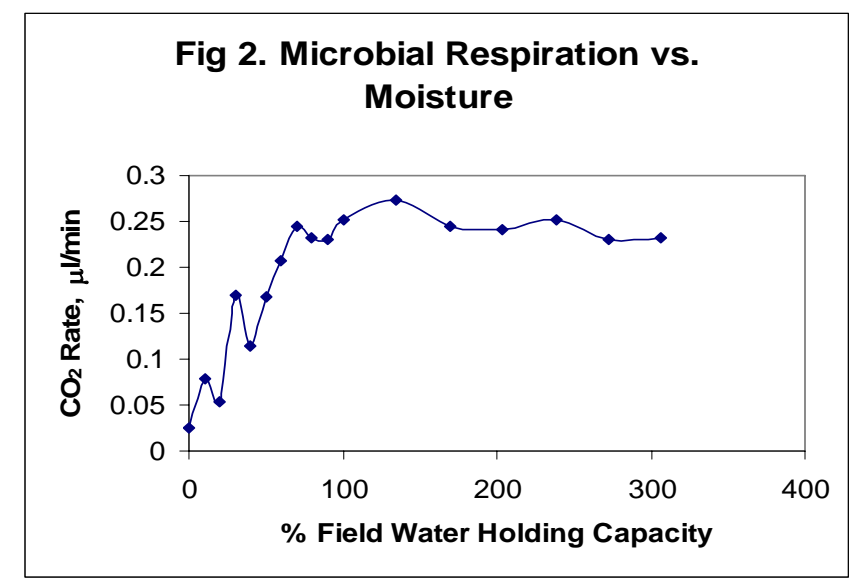

Figure 2. Microbial $\mathrm{CO}_{2}$ Production From Biodegradation of Hydrocarbons in Soil at Different Water Contents

Artificial seawater (“ASW”; 0.425 M sodium chloride, 0.009 M potassium chloride, $0.0093 \mathrm{M}$ calcium chloride, 0.0255 M magnesium sulfate, $0.023 \mathrm{M}$ magnesium chloride, and $0.002 \mathrm{M}$ sodium bicarbonate, $\mathrm{pH}$ 8.0) was used to evaluate the relationship between salinity and microbial respiration. Different concentrations of sodium chloride $(\mathrm{NaCl})$ were used to obtain different salinities. ASW was added to samples at field water holding capacity. All samples were incubated at $35^{\circ} \mathrm{C}$. Each treatment contained $20 \mathrm{~g}$ of soil.

Effects of salinity on biodegradation rates are presented in Figure 3. Microbial respiration increased sharply when water source was switched from deionized water to ASW $(0.025 \mu \mathrm{l} / \mathrm{min}$ to $0.29 \mu \mathrm{l} / \mathrm{min})$. When $\mathrm{NaCl}$ concentration increased beyond that in ASW $(0.43$ $\mathrm{M})$, microbial respiration rates decreased, indicating that microbes are not highly halophilic even though they seem to be able to maintain normal respiration at the sea water equivalent salinity $(0.43 \mathrm{M}$ of $\mathrm{NaCl})$. The results suggest that indigenous microbial population has adapted to sea water equivalent saline environments. However, salt concentrations higher than sea water may have adverse effects on microbial respiration. 


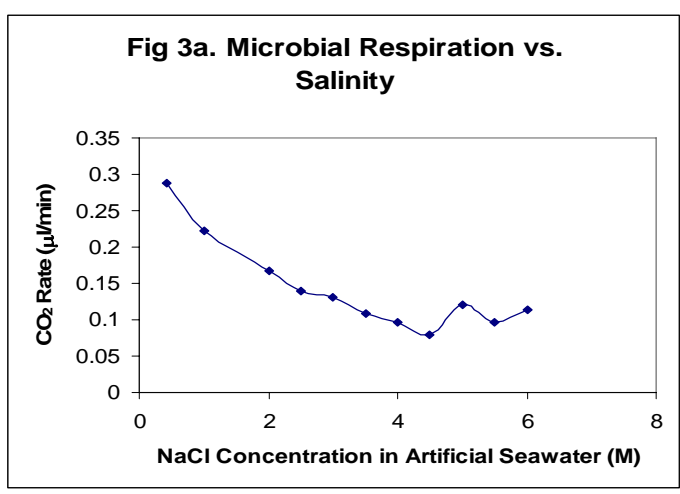

(a)

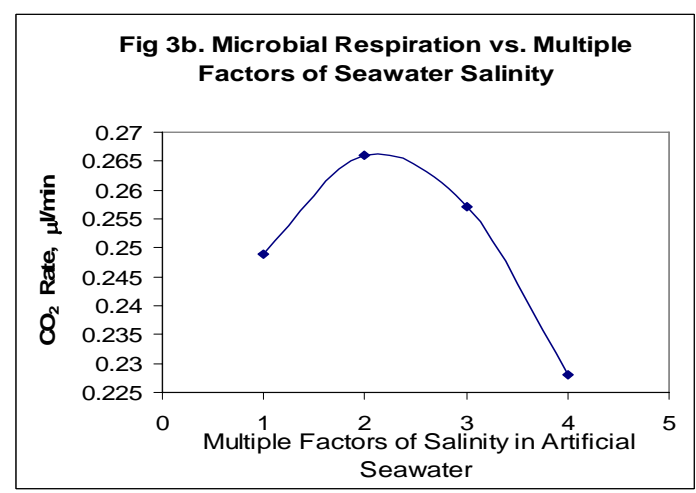

(b)

Figure 3. Microbial $\mathrm{CO}_{2}$ Production From Biodegradation of Hydrocarbons in Soil Amended With Artificial Seawater at Different $\mathrm{NaCl}$ Concentrations (a), and Different Multiples of the Seawater Constituents (b)

\section{Effects of Nutrient Amendments}

Nitrogen was added as ammonium chloride and potassium nitrate in the treatments where nitrogen: carbon ratios of 0-0.5 were achieved. No other nutrients were added to the soil samples. As shown in Figure 4, the addition of ammonium-nitrogen nutrient observably elevated the microbial respiration rates. The increases of microbial activities were linearly proportional to the increasing amount of nitrogen. The results suggest that nitrogen in the soil is a limiting factor to microbial respiration. No saturation effects were observed for nitrogen in the enhancement of microbial respiration rates in the soil, which may be attributed to the high reproduction rates of the soil microorganisms. The addition of nitrate nitrogen had little effect on microbial activity (Figure 5). Ammonium is in a reduced form of nitrogen which is energetically favorable for microbial assimilation and catabolism, which may explain for the difference responses observed between ammonium and nitrate-based nitrogen sources.

In our study, different amounts of phosphate were added to the three soils to evaluate the effect of phosphorus on microbial respiration. Potassium phosphate dibasic was used as the phosphorus source. The molar ratio of $\mathrm{P} / \mathrm{C}$ was added to the range of 0.003 to 0.05 . Nitrogen was maintained at $\mathrm{N} / \mathrm{C}=0.1: 1$. All samples were incubated in the dark at $35^{\circ} \mathrm{C}$. The initial addition of phosphorus showed significant enhancement in microbial respiration rates. As shown on Figure 6, samples with $\mathrm{C}: \mathrm{P}=100: 2$ achieved an $117 \%$ increase in $\mathrm{CO}_{2}$ evolution rate, compared to the samples with $\mathrm{C}: \mathrm{P}=100: 0.3$. However, when C:P was increased to above 100:2, no additional enhancement of microbial respiration was detected. The data demonstrated that phosphorus is a very important factor in microbial activity. But this enhancing effect saturates at 
relatively low phosphorus content, presumably due to the limited needs for phosphorus in microbial metabolisms.

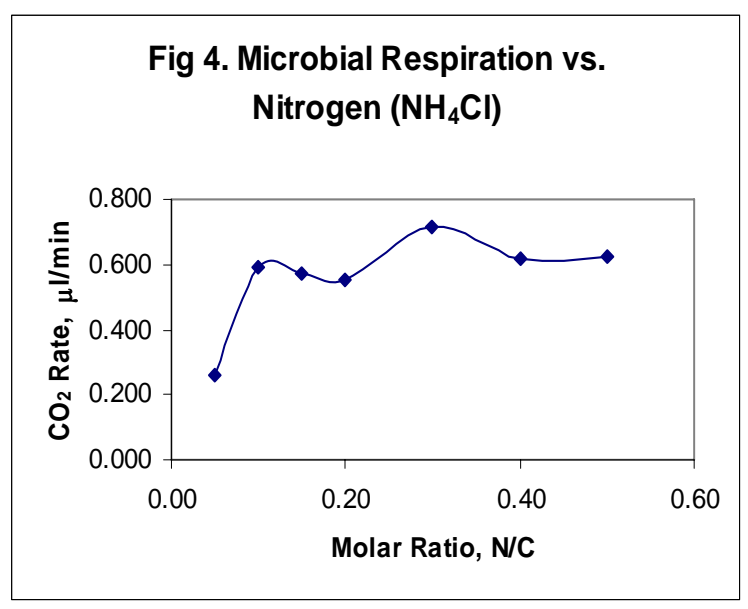

Figure 4. Microbial $\mathrm{CO}_{2}$ Production From Biodegradation of Hydrocarbons in Soil at Different $\mathrm{NH}_{4}$-N/C Ratios

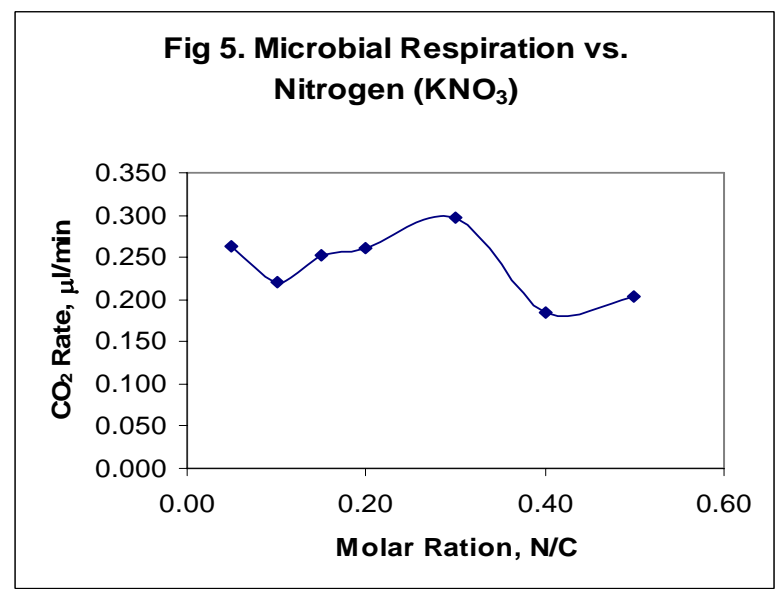

Figure 5. Microbial $\mathrm{CO}_{2}$ Production From Biodegradation of Hydrocarbons in Soil at Different $\mathrm{NO}_{3}-\mathrm{N} / \mathrm{C}$ Ratios 


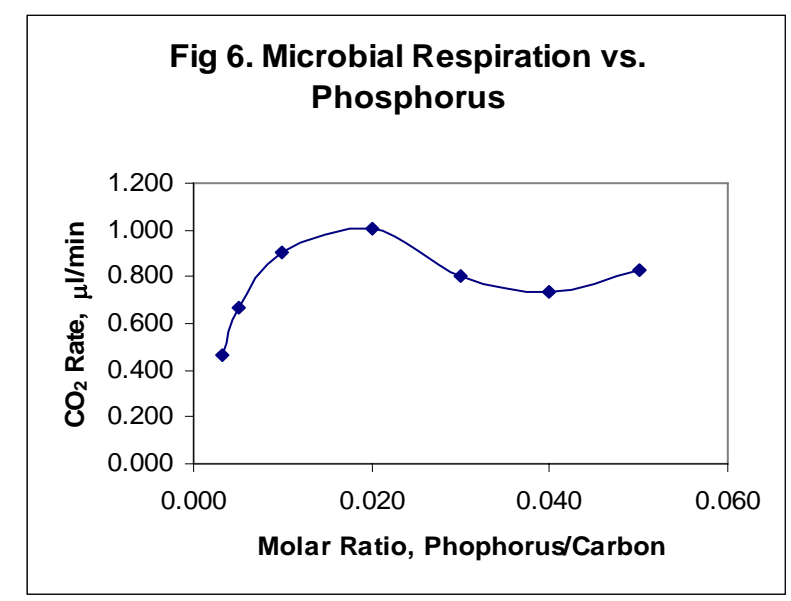

\section{Figure 6. Microbial $\mathrm{CO}_{2}$ Production From Biodegradation of Hydrocarbons in Soil at Different P/C Ratios}

Urea

Urea was evaluated for its potential enhancement of hydrocarbon biodegradation. A laboratory respirometer was used to monitor degradation rates in microcosms. Cumulative carbon dioxide generation and depletion of $\mathrm{TPH}$ were measured as the key indicators of biodegradation. Microcosms were established in triplicates for each of the soil (Plot\#3) in 200$\mathrm{ml}$ glass containers to compare carbon dioxide $\left(\mathrm{CO}_{2}\right)$ production rates. Each microcosm consisted of $20 \mathrm{~g}$ of soil. One treatment set from each soil was treated as a control with no nitrogen amendment. Additional treatments from each soil were amended with $\mathrm{NH}_{4} \mathrm{Cl}$ and urea using C:N molar ratios at 100:5, 100:10, 100:15, 100:20, 100:30, and 100:40. Soils were incubated in a water bath at $35^{\circ} \mathrm{C}$, and the gravimetric water content of the soils was raised to FWC. Additional microcosms were established in triplicates for the soil in 200-ml glass containers to monitor $\mathrm{CO}_{2}$ accumulation over a 200-hour period. Each microcosm consisted of $100 \mathrm{~g}$ of soil. One set of microcosms was treated as a control with no nitrogen amendment. Additional triplicate sets of microcosms were amended with $\mathrm{NH}_{4} \mathrm{Cl}$ and urea using $\mathrm{C}: \mathrm{N}$ mass ratios: 40:1, 20:1, and 10:1. Soils were incubated in a water bath at $35^{\circ} \mathrm{C}$, and the gravimetric water content of the soils was raised to FWC.

$\mathrm{CO}_{2}$ accumulation measured in the microcosms containing soil (6.0 \% of TPH) indicates urea addition has no observable effects on hydrocarbon biodegradation, as shown in Figure 7. Direct measurements of TPH after 200 hours demonstrate that urea addition decreases the rate of hydrocarbon degradation (Figure 8). TPH concentrations declined $46.4 \%$ from $5.97 \%$ to $3.20 \%$ in the controls while the addition of $0.269 \mathrm{~g}$ of urea only achieved a $43.0 \%$ depletion of TPH (6.0 $\%$ to $3.4 \%$ ). Similar results were observed in treatments with $0.537 \mathrm{~g}$ and $1.07 \mathrm{~g}$ of urea amendments. Although the residual TPH was less in the treatments with $1.07 \mathrm{~g}$ of urea than that 
with $0.269 \mathrm{~g}$ and $0.537 \mathrm{~g}$ of urea addition, TPH concentrations are still greater than that from the controls, indicating that increased amount of urea amendments may have adverse effects on biodegradation of the petroleum-impacted soils from Egypt. A possible cause of inhibition by urea is the existence of zero or low populations of urease-producing bacteria in the soil. Since urease is the essential enzyme for the breakdown of urea to ammonium in soil, a low population of urease-producing bacteria would not efficiently convert urea to ammonium.

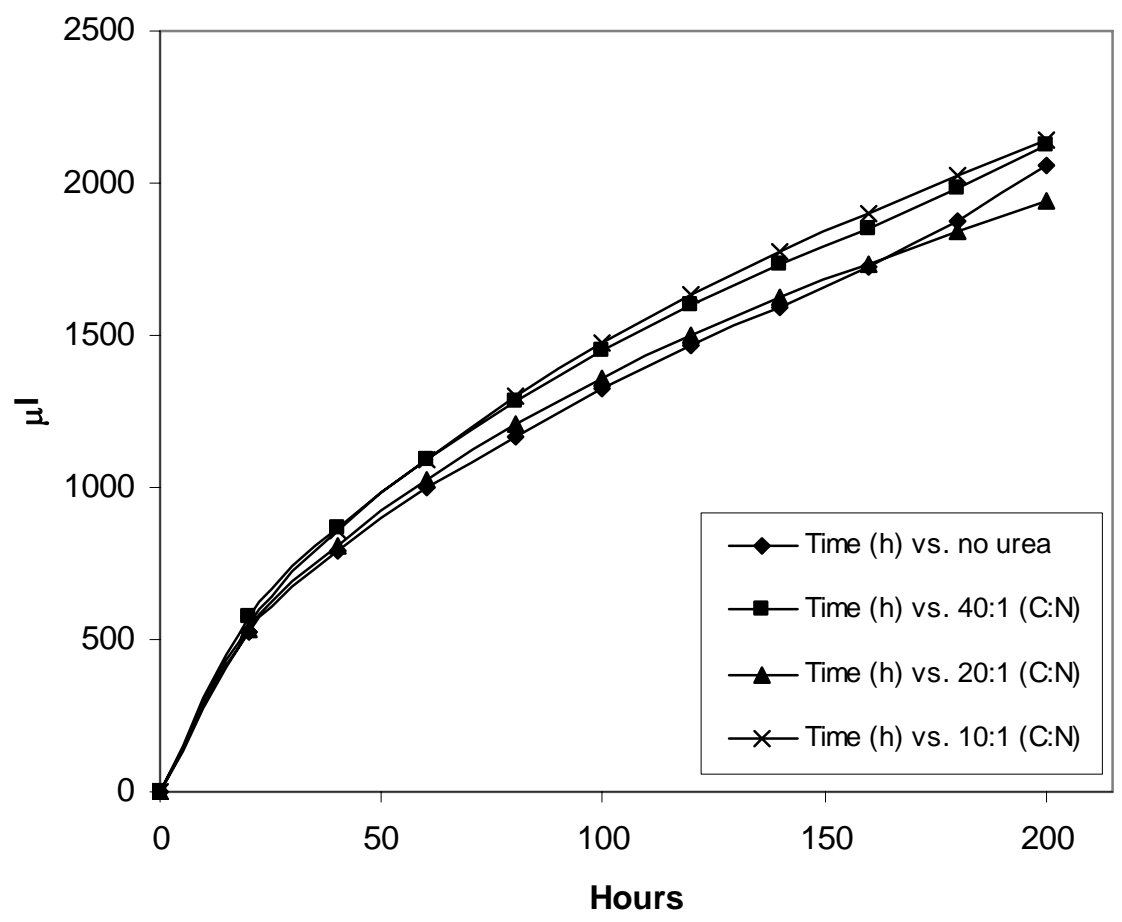

Figure 7. Urea Amendments in Biodegradation (Microbial Respiration) 


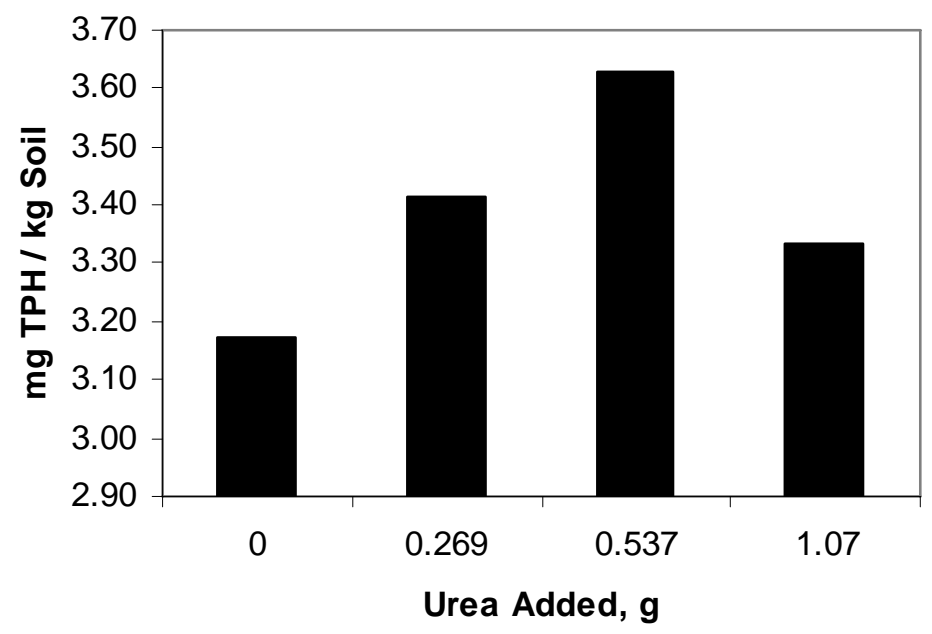

Figure 8. Amounts of Urea Amendments in Biodegradation (TPH Degradation)

In summary, the current study shows that urea failed to enhance biodegradation of petroleum contaminants in an arid soil from northeastern Egypt at both low and high TPH concentrations. Based on the existing data, urea presumably inhibits the enzymes responsible for petroleum degradation in the soil samples collected from the Egypt site. Urea may not be a good nutrient source for bioremediation of petroleum contaminants in soils with similar chemical and physical characteristics. Results from this study suggest that applications of urea in enhanced biodegradation may be site specific (Jin and Fallgren, 2007). Therefore, the use of urea in biodegradation warrants pre-application site characterizations and laboratory studies before conducting field work

\section{Biotreatment Cell (Biocell) Studies}

The biotreatment cells (biocells or solid-phase bioreactors) used in this project was designed based on the data obtained from the previous biodegradation studies on the impacted soil samples collected from the Egyptian sites. Tests were done in two different biocell systems to provide adequate and repeatable parameters to facilitate field operations. Water and nutrient recirculations were used in both systems considering the draught climate onsite. System I is a "mini-biocell" that is manually operated. Respirometer was set up in parallel to monitor microbial respiration, as indicated in carbon dioxide $\left(\mathrm{CO}_{2}\right)$ evolution. A photograph of the setup for System I is shown in Figure 9 and described in the procedure section. System II is a scaleddown version of a skid-mounted or in situ biocell in the field. It is fully automated and contained to minimize water evaporation and nutrient loss. A photograph of the actual unit is shown in Figure 10 (diagram of the design is shown in Appendix B). 


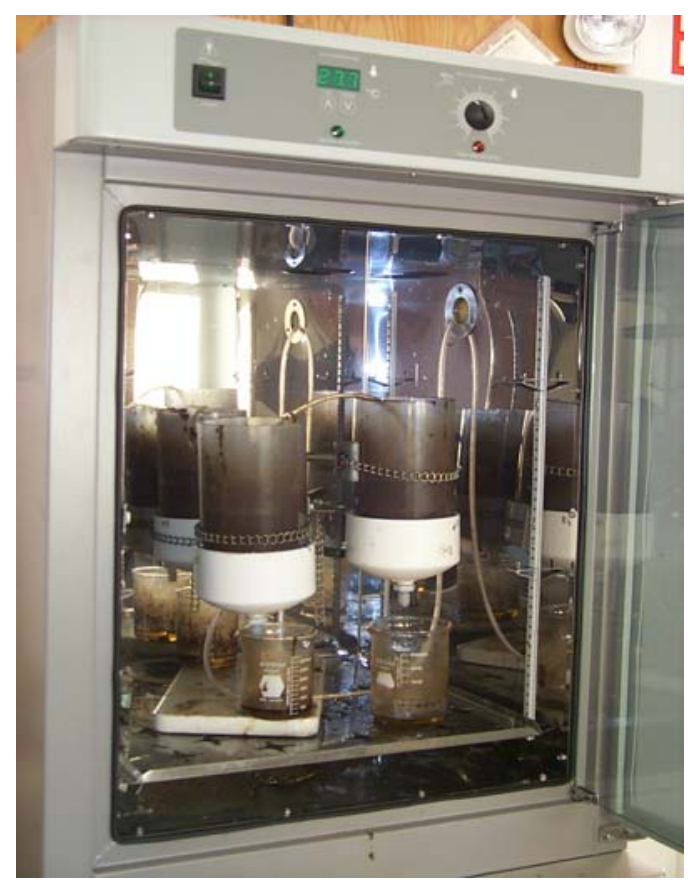

Figure 9. Photograph of the “mini-biocell” System I setup

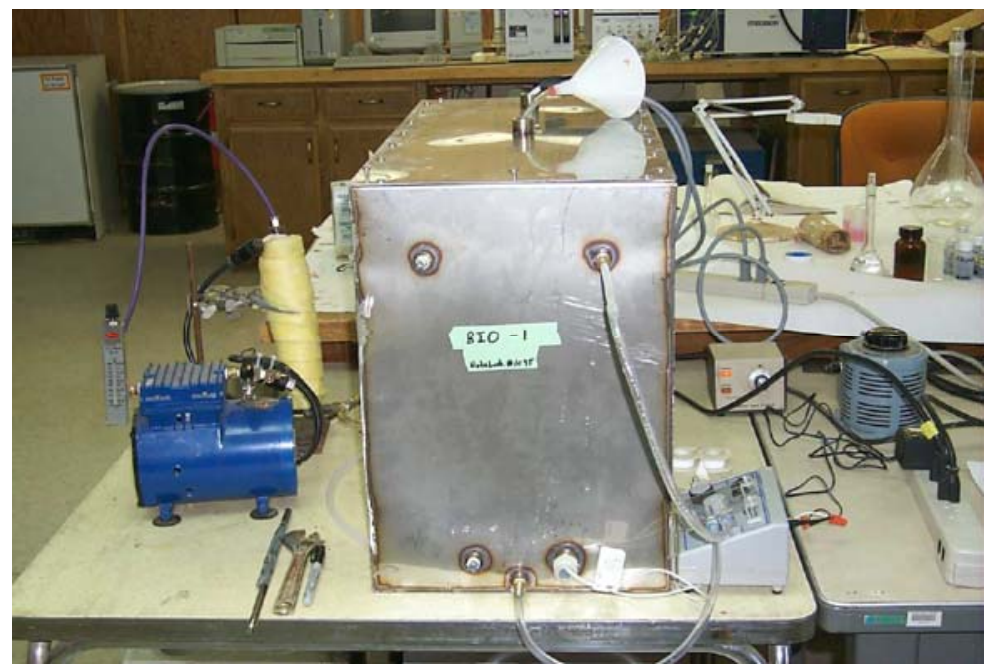

Figure 10.Photograph of the bench-scale biocell (System II)

System I: Mini-Biocells Test

“Mini-biocells" were established in PVC columns in triplicates as shown in Figure 9. Soils collected from Egyptian site plot \#2 were spiked with10W-30 motor oil and diesel at 1:1 (w/w) to reach an approximate total petroleum hydrocarbon (TPH) concentration at $13 \%$. The unspiked soil had an approximate TPH concentration of 3.5\%, mostly constituting of diesel, 
crude and drill cuttings. Open end columns (3 liter in volume) were used to set up the minibiocells. Fiber screen was used at the bottom of each column to substitute sand and gravel layers. An aquarium pump was used to provide aeration into the columns. Air tubes were perforated and inserted into the soil samples to supply oxygen, air flow was top-down. Nutrient amendments were applied in irrigation water (deionized water) to reach the ratio of $\mathrm{C}: \mathrm{N}: \mathrm{P}=110: 20: 1.5$. Initial moisture content was maintained at $30 \%$, which is close to the field saturation point of the soil (33\%). Leachate was collected and recirculated into each column every $6 \mathrm{hr}$. All columns were set up inside an incubator with temperature at $50^{\circ} \mathrm{C}$ and $20^{\circ} \mathrm{C}$, to simulate the summer and winter temperatures in the field. Soil samples were collected before each recirculation (every 12-24 hr). The TPH was measured in soil samples by using standard EPA method 1664b. Due to the continuous air flow inside the mini-biocell and bench scale biocell, monitoring of microbial respiration, as indicated by $\mathrm{CO}_{2}$ accumulation, is infeasible. Therefore, a respirometer was running in parallel to measure $\mathrm{CO}_{2}$ evolution in separate samples that were set up under the same condition as those in the mini-biocells. Soils without any nutrient/water amendments were used as "non-treatment" controls. Temperature was maintained at $50^{\circ} \mathrm{C}$ and $20^{\circ} \mathrm{C}$ for all active and control samples in the two treatment groups. Oxygen concentration was maintained adequate throughout the test by setting the automatic system purge at every $6 \mathrm{hr}$. Background hydrocarbon concentration in TPH was measured at 12.47\%. Biodegradation efficiency of the mini-biocells was determined by the change in $\mathrm{TPH}$ concentrations and microbial activities through $\mathrm{CO}_{2}$ measurement.

During the first $48 \mathrm{hr}$ of operation at $50^{\circ} \mathrm{C}$, TPH concentration declined $64 \%$ (from $12.47 \%$ to $4.46 \%$ ). A TPH degradation profile is shown in Figure 11 . The degradation rates decreased after $48 \mathrm{hr}$; however, the degradation was active enough to reduce TPH concentration to $2.69 \%$ within 9.5 days. We attributed the slowed-down degradation rates to the accumulation of $\mathrm{CO}_{2}$ and shortage in oxygen supply due to the limitation of the maximum pump output and biomass buildup in the columns. Heavy end hydrocarbons such as polycyclic aromatic hydrocarbons (PAHs) tend to sorb on soil particles and limit microbial accessibility. This might have prolonged the total TPH degradation in this study. This problem may be solved with the bottom-up configuration and higher pump output in the standard biocell. Addition of surfactant will also increase the bioavailability of PAHs. The profiles of accumulation of $\mathrm{CO}_{2}$ in the active treatments and controls are shown in Figure 12. $\mathrm{CO}_{2}$ evolution in the active samples was by average 18 fold higher than that in the controls. Data of $\mathrm{CO}_{2}$ releasing rates are consistent with the $\mathrm{TPH}$ and $\mathrm{CO}_{2}$ cumulative data as shown in Figure 13. Throughout the testing period of 10 days, $\mathrm{pH}$ readings in the mini-biocell were stable at 7.0-7.3. 


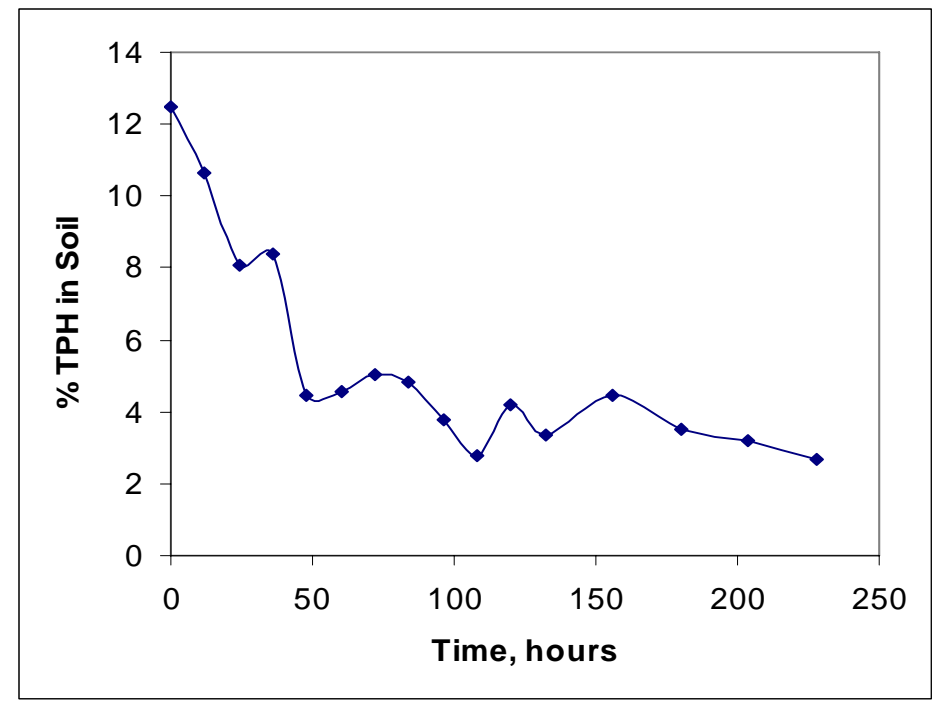

Figure 11. Biodegradation of TPH in System I at $50^{\circ} \mathrm{C}$

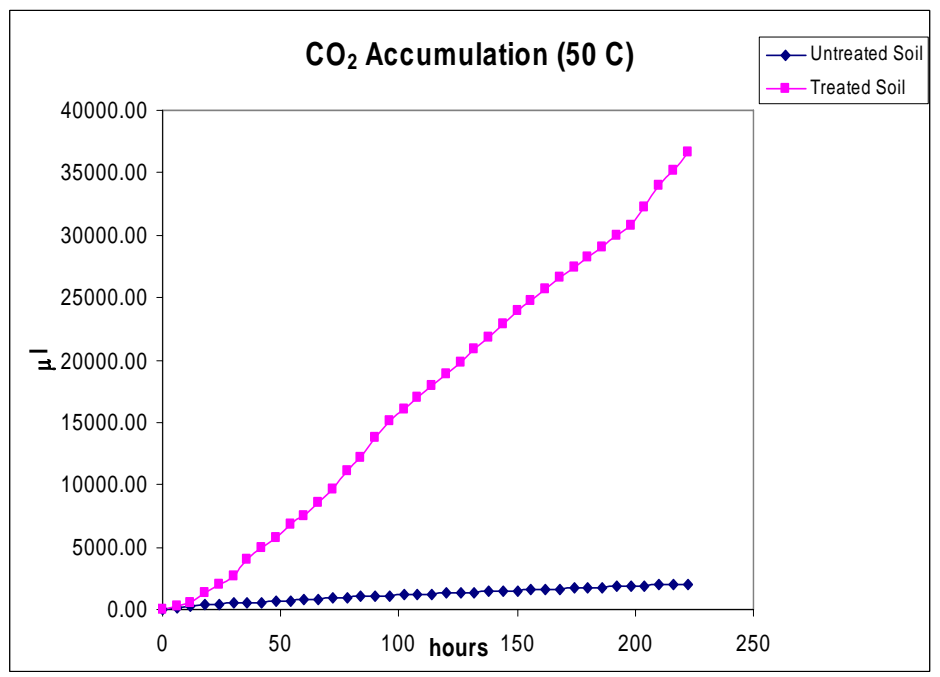

Figure 12. Cumulative $\mathrm{CO}_{2}$ Production in System $\mathrm{I}$ at $50^{\circ} \mathrm{C}$ 


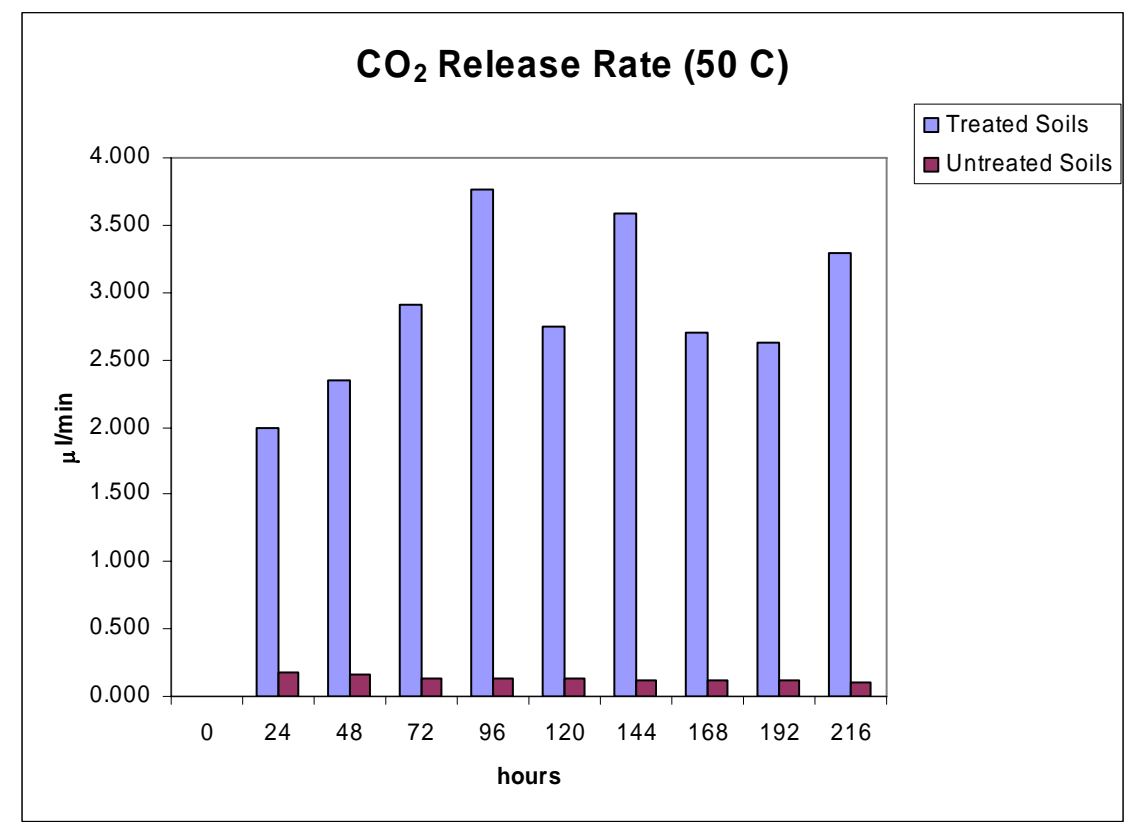

Figure 13. Rate of $\mathrm{CO}_{2}$ Production in System $\mathrm{I}$ at $50^{\circ} \mathrm{C}$

During the first $48 \mathrm{hr}$ of operation at $20^{\circ} \mathrm{C}$, the TPH concentration declined $35 \%$ (from $12.47 \%$ to $8.07 \%$ ). A degradation profile is shown on Figure 14 . At $84 \mathrm{hr}$ of treatment, TPH concentration decreased to $6.8 \%$ (55\% TPH degradation), and the degradation leveled off from the same point on. TPH concentration remained unchanged after $228 \mathrm{hr}$ of treatment. We attributed the observation to the accumulation of $\mathrm{CO}_{2}$ and shortage in oxygen supply due to the limitation of the maximum pump output and biomass buildup in the columns. Also, heavy end hydrocarbons such as polyaromatic hydrocarbons (PAHs) tend to adsorb onto soil particles and limit microbial accessibility. Compared to the results from $50^{\circ} \mathrm{C}$ samples, it appears that some microbial activities present at $50^{\circ} \mathrm{C}$ were absent in samples at $50^{\circ} \mathrm{C}$. This could be caused by the onset of thermophilic species at $50^{\circ} \mathrm{C}$ or simply the enzymatic activities at $20^{\circ} \mathrm{C}$ were lower than that at $50^{\circ} \mathrm{C}$. We expect the degradability to be enhanced if bottom-up configuration and higher pump output are used in the standard biocell. Addition of surfactant may also increase the bioavailability of PAHs in field operations. The profiles of accumulation of $\mathrm{CO}_{2}$ in the active treatments and controls are shown on Figure 15. $\mathrm{CO}_{2}$ evolution in the active samples was by average 7 folds higher than that in the controls. Data of $\mathrm{CO}_{2}$ releasing rates (Figure 16) are consistent with the TPH and $\mathrm{CO}_{2}$ cumulative data. Throughout the testing period, $\mathrm{pH}$ readings in the mini-biocell were stable at 7.0-7.3. 


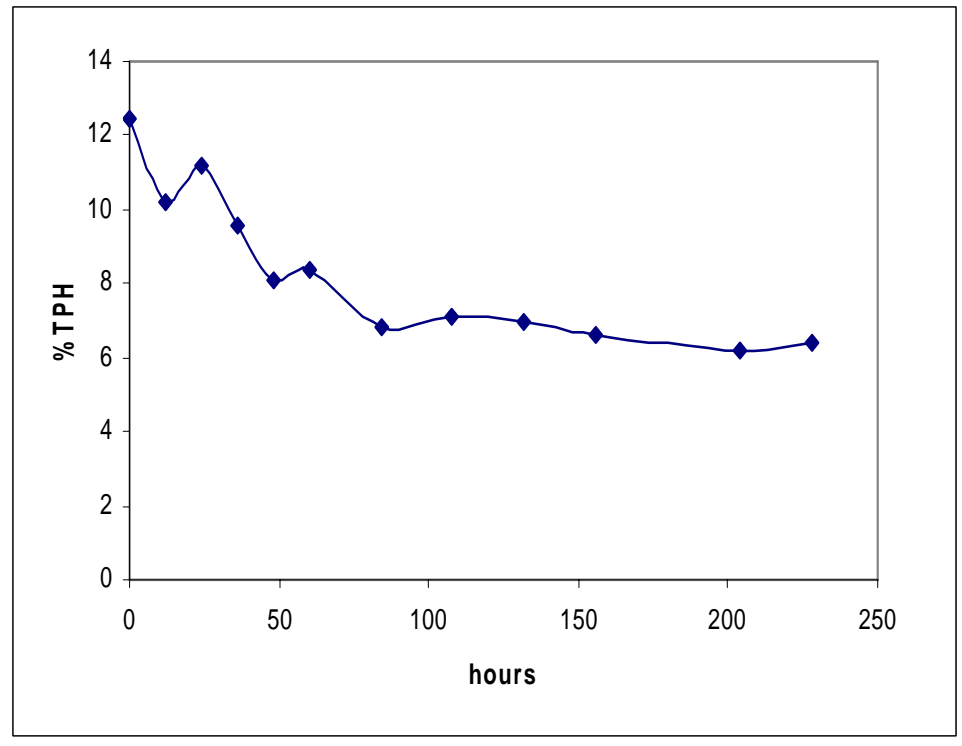

Figure 14. Biodegradation of TPH in System I at $20^{\circ} \mathrm{C}$

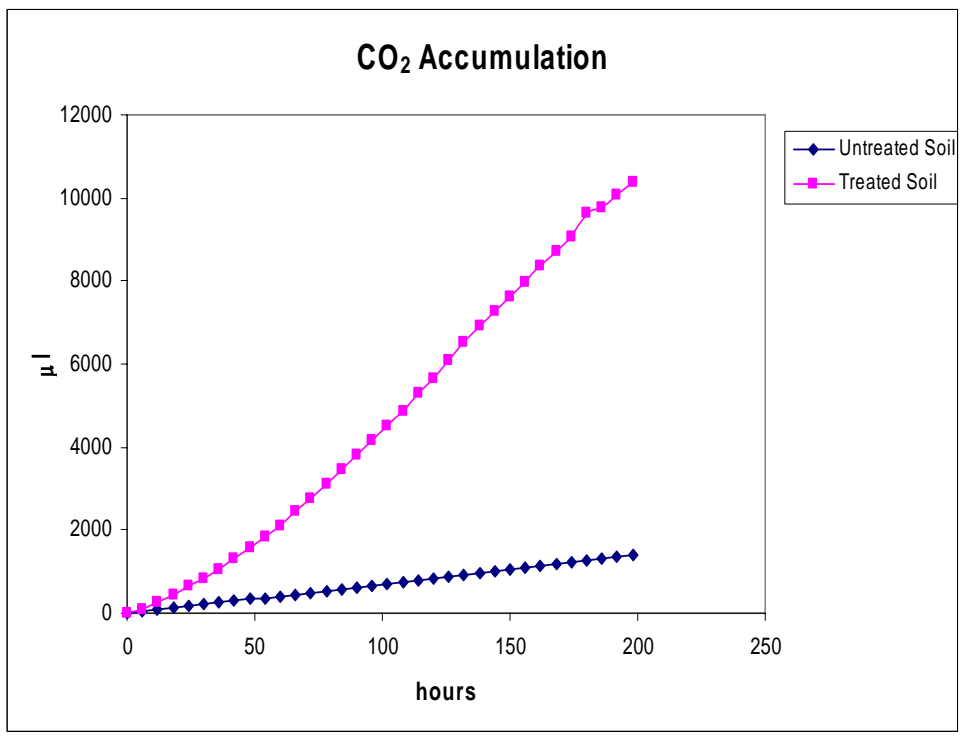

Figure 15. Cumulative $\mathrm{CO}_{2}$ Accumulation in System I at $20^{\circ} \mathrm{C}$ 


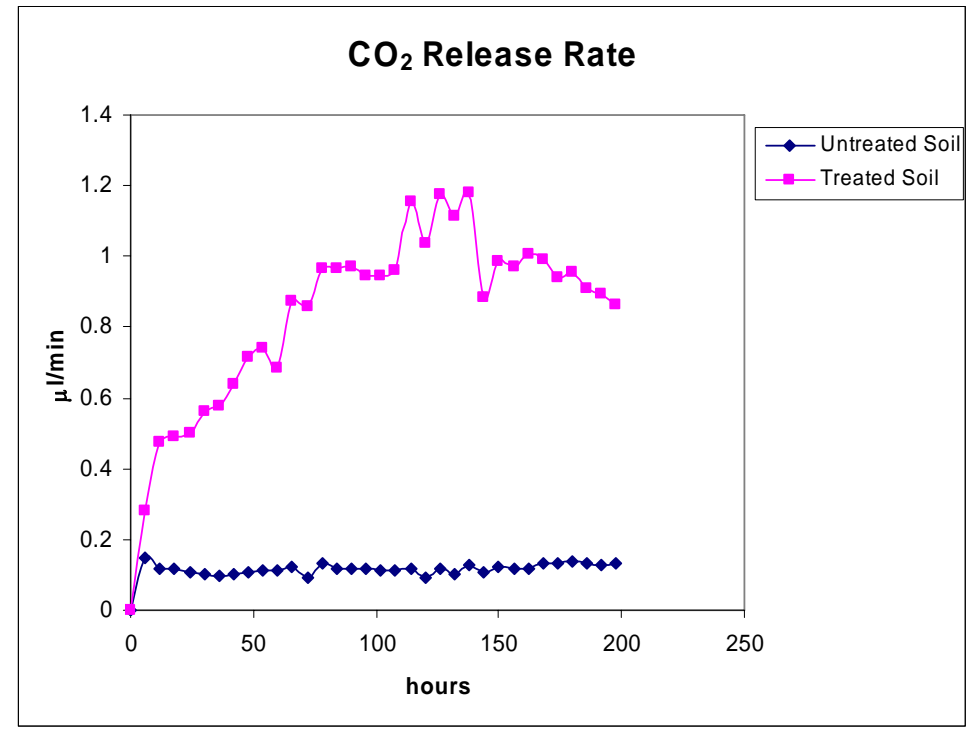

Figure 16. Rate of $\mathrm{CO}_{2}$ Production in System $\mathrm{I}$ at $20^{\circ} \mathrm{C}$

The mini-biocell tests have demonstrated a highly efficient degradation of petroleum contaminants, when favorable nutrients and moisture are maintained through recirculation. Degradation rates are closely associated with temperature. Amount of TPH degraded at $50^{\circ} \mathrm{C}$ was approximately 2.4 times more than that at $20^{\circ} \mathrm{C}$; even biodegradation was considered highly active under both temperatures. Evolution of $\mathrm{CO}_{2}$ at $50^{\circ} \mathrm{C}(30,818 \mu \mathrm{l}$ at $198 \mathrm{hr})$ was 2.9 times more than that at $20^{\circ} \mathrm{C}(10,398 \mu \mathrm{l}$ at $198 \mathrm{hr})$. The difference of $\mathrm{CO}_{2}$ evolution between the treated and untreated samples was also different when tests were conducted under the two temperatures. At $50^{\circ} \mathrm{C}$, treated samples accumulated 18 times of $\mathrm{CO}_{2}$ when compared to the untreated samples. This number was 7 when treatments were incubated at $20^{\circ} \mathrm{C}$. These results are consistent with the difference in TPH degradation profiles.

To further evaluate the temperature factor in biodegradation in System I, at the completion of the $20^{\circ} \mathrm{C}$ test, temperature was raised to $50^{\circ} \mathrm{C}$. Interestingly, the previous stabilized TPH concentration started to decline at the point where temperature was raised. As shown in Figure 17, TPH concentration declined from 6.8\% to $3.4 \%$ within $108 \mathrm{hr}$ post temperature shift. Consistent changes were also observed in $\mathrm{CO}_{2}$ profiles, as shown on figures 10. Evolutions of $\mathrm{CO}_{2}$ significantly increased when temperature was adjusted from $20^{\circ} \mathrm{C}$ to $50^{\circ} \mathrm{C}$ (Figure 18). These results supported our hypothesis that thermal strains or thermal enzymes may be more efficient in degrading the petroleum contaminants in this system. 


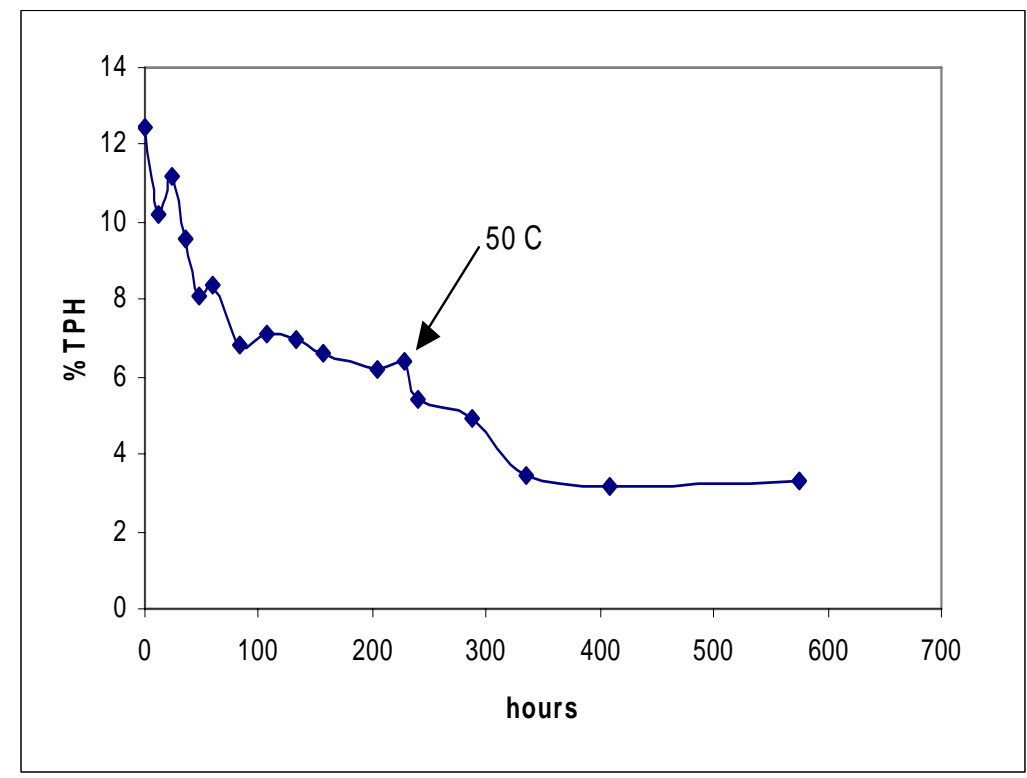

Figure 17. Biodegradation of TPH in System I With Temperature Adjustment

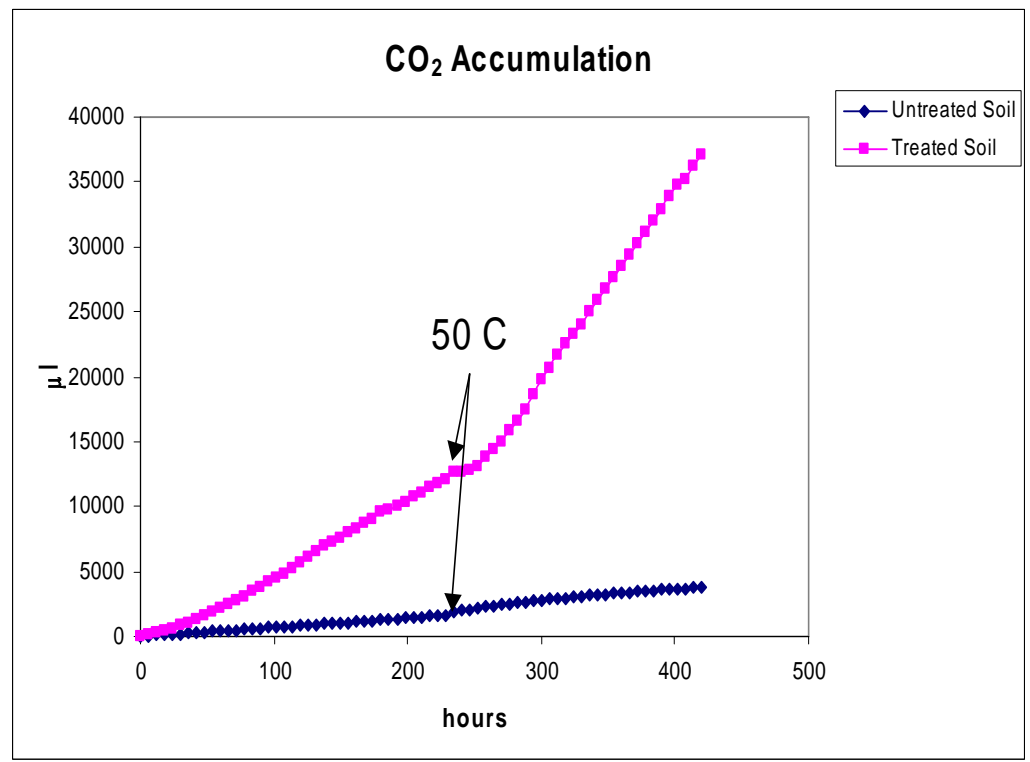

Figure 18. $\mathrm{CO}_{2}$ Accumulation in System I With Temperature Adjustment

System II: Bench-Scale Biocell Tests

A bench-scale biocell was designed and built in a stainless steel box as shown on Figure 2. Soils collected from Egyptian site plot \#2 were spiked with10W-30 motor oil and diesel at 1:1 (w/w) to reach an approximate total petroleum hydrocarbon (TPH) concentration at $13 \%$. The 
unspiked soil had an approximate $\mathrm{TPH}$ concentration of 3.5\%, mostly constituting of diesel, crude and drill cuttings. HDPL liner, sand (3') and gravel layers (2') were placed at the bottom of the biocell. $10.9 \mathrm{~kg}$ of contaminated soil was placed on top of the sand layer. A "Thomas" air pump (Sheboygen, WI) was used to provide aeration to the biocell. Air was supplied at a rate of $100 \mathrm{ml} / \mathrm{min}$. "Fyrite Pro" gas analyzer (New Kensington, PA) was used to measure oxygen concentration in the biocell. Air flow was bottom up. “Glas-Col” heat tape (Terre Haute, IN) and a power controller were used to heat the soil to designed temperatures. A temperature probe was used to continuously monitor temperature changes inside the biocell. Nutrient amendments were applied in irrigation water (tap water) to reach the ratio of $\mathrm{C}: \mathrm{N}: \mathrm{P}=110: 20: 1.5$. Initial moisture content was maintained at $30 \%$, which is close to the field saturation point of the soil (33\%). Leachate was collected in the side chamber of the biocell and recirculated into soil automatically by using a VWR peristaltic pump. Sprinkler system was used to evenly distribute the recirculated water from the top of the biocell. Temperatures were maintained at $50^{\circ} \mathrm{C}$ to simulate summer in the field. Composite soil samples were collected from the three sampling ports on the biocell (every 12-24 hr). TPH was measured in soil samples by using EPA method 1664b.

Due to the continuous air flow inside the biocell, monitoring of microbial respiration, as indicated by $\mathrm{CO}_{2}$ accumulation, is infeasible. Therefore, a respirometer was running in parallel to measure $\mathrm{CO}_{2}$ evolution in separate samples that were set up under the same condition as those in the biocells. Soils without any nutrient/water amendments were used as "non-treatment" controls. Temperature was maintained at $50^{\circ} \mathrm{C}$ for all active and control samples in the two treatment groups. Oxygen concentration was maintained adequate throughout the test by setting the automatic system purge at every $6 \mathrm{hr}$.

Background hydrocarbon concentration in TPH was determined to be $13.37 \%$. Biodegradation efficiency of the mini-biocells was determined by the change in TPH concentrations and microbial activities through $\mathrm{CO}_{2}$ measurement. Within the first $48 \mathrm{hr}$ of operation at $50^{\circ} \mathrm{C}$, the TPH concentration declined $69.6 \%$ (from $13.37 \%$ to $4.06 \%$ ). After another $24 \mathrm{hr}$, TPH concentrations were reduced to 2.05\% (Figure 19). TPH concentration leveled off afterwards (no significant change during additional $72 \mathrm{hr}$ of operation). We attribute the residual TPH to the heavy end hydrocarbons such as polycyclic aromatic hydrocarbons (PAHs), which tend to adsorb on soil particles and limit microbial accessibility. They are also more recalcitrant to microbial degradation. Addition of surfactant may increase the bioavailability of PAHs. 


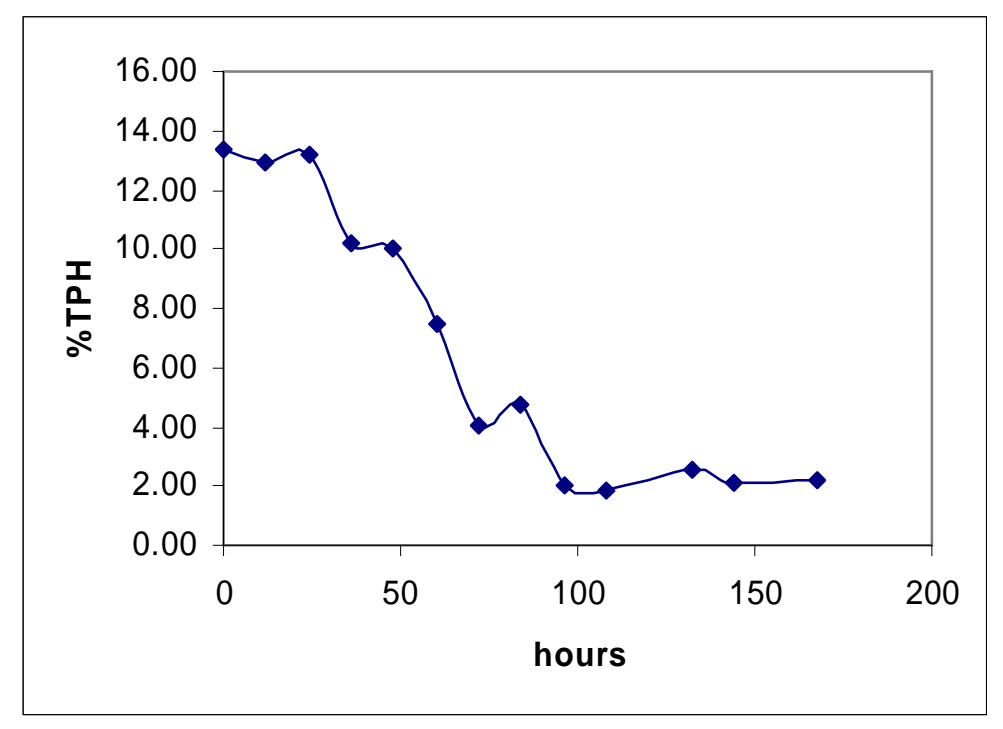

Figure 19. Biodegradation of TPH in System II at $50^{\circ} \mathrm{C}$.

Results from the both systems are consistent and demonstrating the highly efficient degradation of petroleum contaminants through biodegradation that is achieved by our recirculating design. However, the rates from the laboratory study may not be the rates a full size field biocell will achieve. But we believe the field performance may be similar or even exceeding the results in the laboratory study. First of all, due to the limitation of make-up material, starting TPH concentration in the laboratory system was high. Sand and other material can be mixed with the petroleum contaminants to offer more permeability and dilution of TPH. Secondly, the aeration equipment in the field will be able to satisfy the oxygen supply when biomass builds up rapidly during the initial treatment. Thirdly, some engineering tools may be used to optimize a field biocell. For example, surfactant, gypsum, straw, and/or sawdust may be mixed with the impacted soil or sludge to increase soil permeability and associated rates of oxygen, contaminants, nutrients, and moisture transfer. Agents to adjust $\mathrm{pH}$ such as lime or acid may be added if the soil $\mathrm{pH}$ is outside of the optimal range of 6-8.

The performance of the bench-scale biocell led to a conceptual design of a field-scale in situ biocell (Figure 20). The biocell was to be implemented at the Ras Shukheir site in Egypt to treat the contaminated soils mixed with sludge. 


\section{SUMMARY}

Western Research Institute in conjunction with TechLink Environmental, Inc. and the U.S. Department of Energy conducted laboratory studies to evaluate major parameters that contribute to the bioremediation of petroleum-contaminated drill cuttings using land farming and to develop a biotreatment cell to expedite biodegradation of hydrocarbons. Physical characteristics such as soil texture, hydraulic conductivity, and water retention were determined for the petroleum hydrocarbon contaminated soil from a site in Egypt. These physical characteristics are important design parameters for bioremediation since they influence the availability of water to microorganisms. Three PSA methods were used to determine soil texture which was determined to be loamy sand to sand. The high hydraulic conductivity and low water retention observed for the contaminated soil are due to the combination of the soil texture and the hydrophobic organic material (i.e., hydrocarbons) adsorbed to the soil particles. The adsorbed hydrocarbons repel water which increases hydraulic conductivity and lowers water retention.

The effects of environmental parameters such as temperature, water content, salinity, and nutrient contents were investigated using respirometry. Temperature appeared to have the greatest influence on biodegradation rates where high temperatures $\left(>50^{\circ} \mathrm{C}\right)$ favored biodegradation. This is due to a possible abundance of thermophilic bacteria that may exist in soil where surface temperatures are high. High nitrogen content in the form of ammonium enhanced biodegradation as well did the presence of water near field water holding capacity. Urea was not a good source of nitrogen and has detrimental effects for bioremediation for this site soil. Artificial sea water had little effect on biodegradation rates, but biodegradation rates decreased after increasing the concentrations of salts. Biotreatment cell (biocell) tests demonstrated hydrocarbon biodegradation can be enhanced substantially when utilizing a leachate recirculation design. Due to the water repulsion (high hydraulic conductivity), nutrients and water treatments infiltrate to the bottom of the biocell. The recirculation of the leachate increases bioavailability and further enhances biodegradation of hydrocarbons in the soil. A $72 \%$ reduction of hydrocarbon concentration was observed with a 72-h period at a treatment temperature of $50^{\circ} \mathrm{C}$. Overall, this study demonstrates the investigation of the effects of environmental parameters on bioremediation is important in designing a bioremediation system to reduce petroleum hydrocarbon concentrations in impacted soils. 


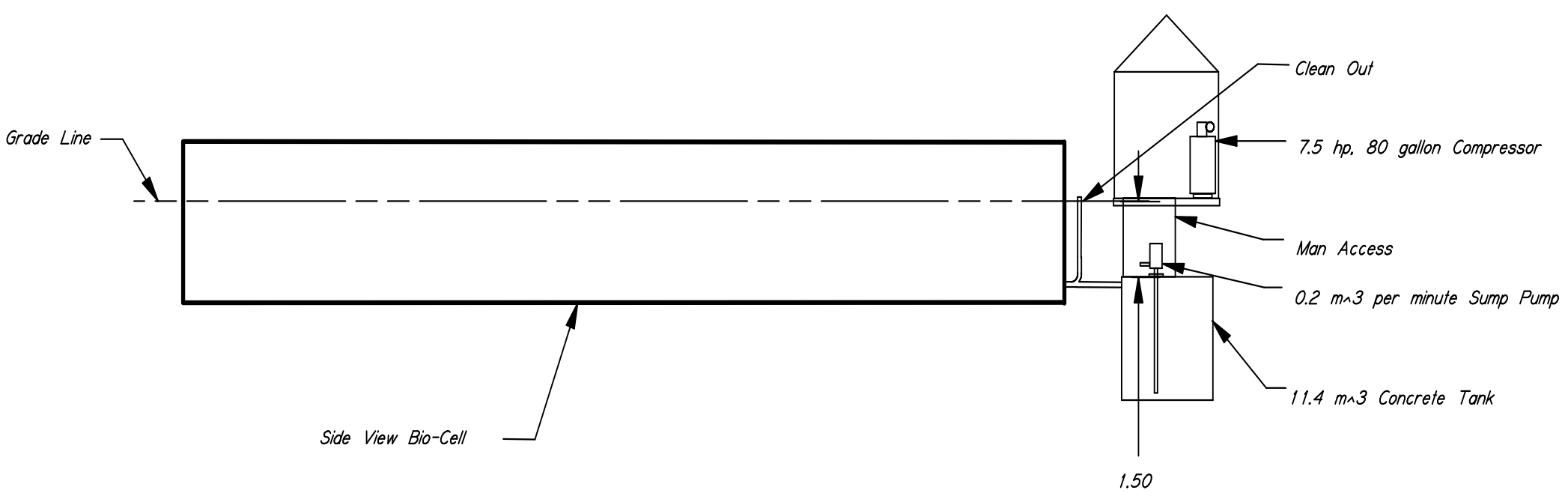

Western Research Institute

9-22-2005

Figure 20. Side View of a Design for a Field-Scale Biocell. 


\section{REFERENCES}

Alexander, M. 1998. Biodegradation and Bioremediation. Academic Press, $2^{\text {nd }}$ ed. 453 pp.

Anderson, W.C. 1996. Innovative Site Remediation Technology. Vol. 1: Bioremediation. Springer Verlag, 288 pp.

Anderson, W.C. (ed.). 1995. Innovative Site Remediation Technology. Vol. 1: Bioremediation. American Academy of Environmental Engineers.

ASTM. 1998. Standard Guide for Remediation of Ground Water by Natural Attenuation at Petroleum Release Sites. ASTM E 1943-98.

Atlas, R.M. 1991. Microbial hydrocarbon degradation—bioremediation of oil spills. J. Chem. Technol. Biotechnol. 52, 149-156.

Bento, F.M., Camargo, F.A.O., Okeke, B.C., and Frankenberger, W.T. 2005. Comparative bioremediation of soils contaminated with diesel oil by natural attenuation, biostimulation and bioaugmentation. Bioresource Technol. 96, 1049-1055.

Brook, T.R., Stiver, W.H. and Zytner, R.G. 2001. Biodegradation of diesel fuel in soil under various nitrogen addition regimes. Soil Sed. Contam. 10, 539-553.

Duell, L.E. and G.H. Holliday. 1997. Soil Remediation for Petroleum Extraction Industry. Pennwell Press, $2^{\text {nd }}$ ed.

EPA. 1995. Bioremediation of Hazardous Wastes: Research, Development and Field Evaluations. EPA/540/R-95/532.

Flathman, P.E., D.E. Jerger, and J.H. Exner. 1993. Bioremediation: Field Experience. Lewis Publishers.

Gee, G.W. and J.W. Bauder. 1986. Particle-size Analysis. In Methods of Soil Analysis, Part 1. Physical and Mineralogical Methods, Agronomy Monograph No. 9, $2^{\text {nd }}$ ed. American Society of Agronomy, Madison, WI.

Head, I.M. and Swannell, R.P.J. 1999. Bioremediation of petroleum hydrocarbon contaminants in marine habitats. Curr. Opin. Biotechnol. 10, 234-239. 
Hinchee, R.F., J.A. Kittel, and H.J. Reisinger. 1995. Applied Bioremediation of Petroleum Hydrocarbons. Battelle Press.

Jin, S. and P.H. Fallgren. 2007. Site-specific limitations of using urea as a nitrogen source in biodegradation of petroleum wastes in soil. Soil Sed. Contam. 16, 497-505.

Kaufman, A.K. 1993. Selection of bioremediation for site cleanup: decision factors. In Bioremedation: Field Experience. P.E. Flathman, D.E. Jerger, and J.H. Exner (eds.) pp. 51-58.

Piskonen, R., Kapanen, A., Mansikka, T., Rytkonen, J., and Itavaara, M. 2002. Evaluation of bioremediation treatments in shoreline-simulating microcosm. Bioremediation J. 6, 143158.

Sikdar, S.K. 1998. Bioremediation: Principles and Practice. Technomic Publishing Company.

Walworth, J.L. and Reynolds, C.M. 1995. Bioremediation of a petroleum-contaminated cryic soil: effects of phosphorus, nitrogen, and temperature. J. Soil Contam. 4, 299-310.

Zhou, E. and Crawford, R.L. 1995. Effects of oxygen, nitrogen, and temperature on gasoline biodegradation in soil. Biodegradation. 6, 127-140. 
APPENDIX A

Photograph of Respirometer

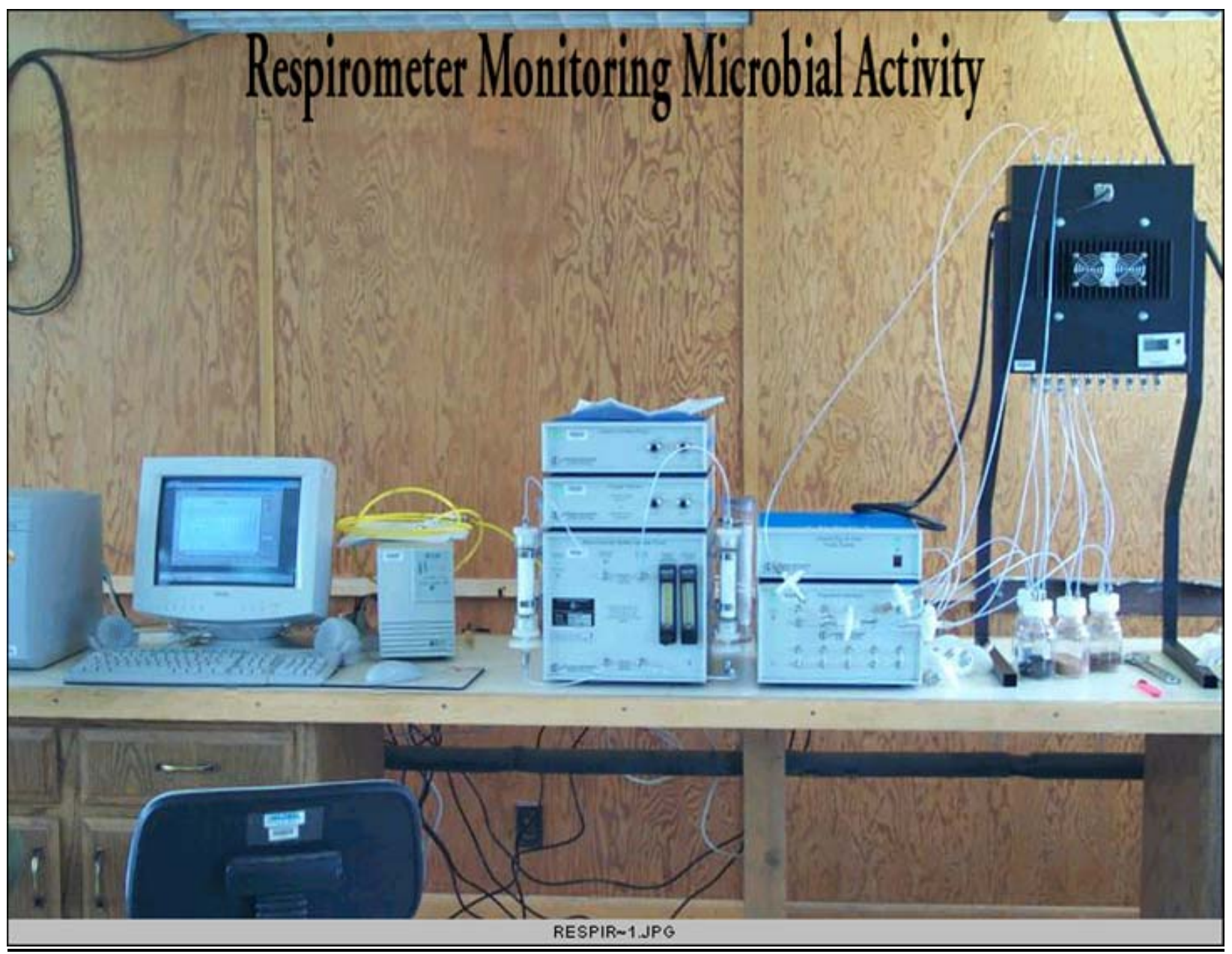




\section{APPENDIX B}

Conceptual Design of Biocell.

SIDE VIEW:

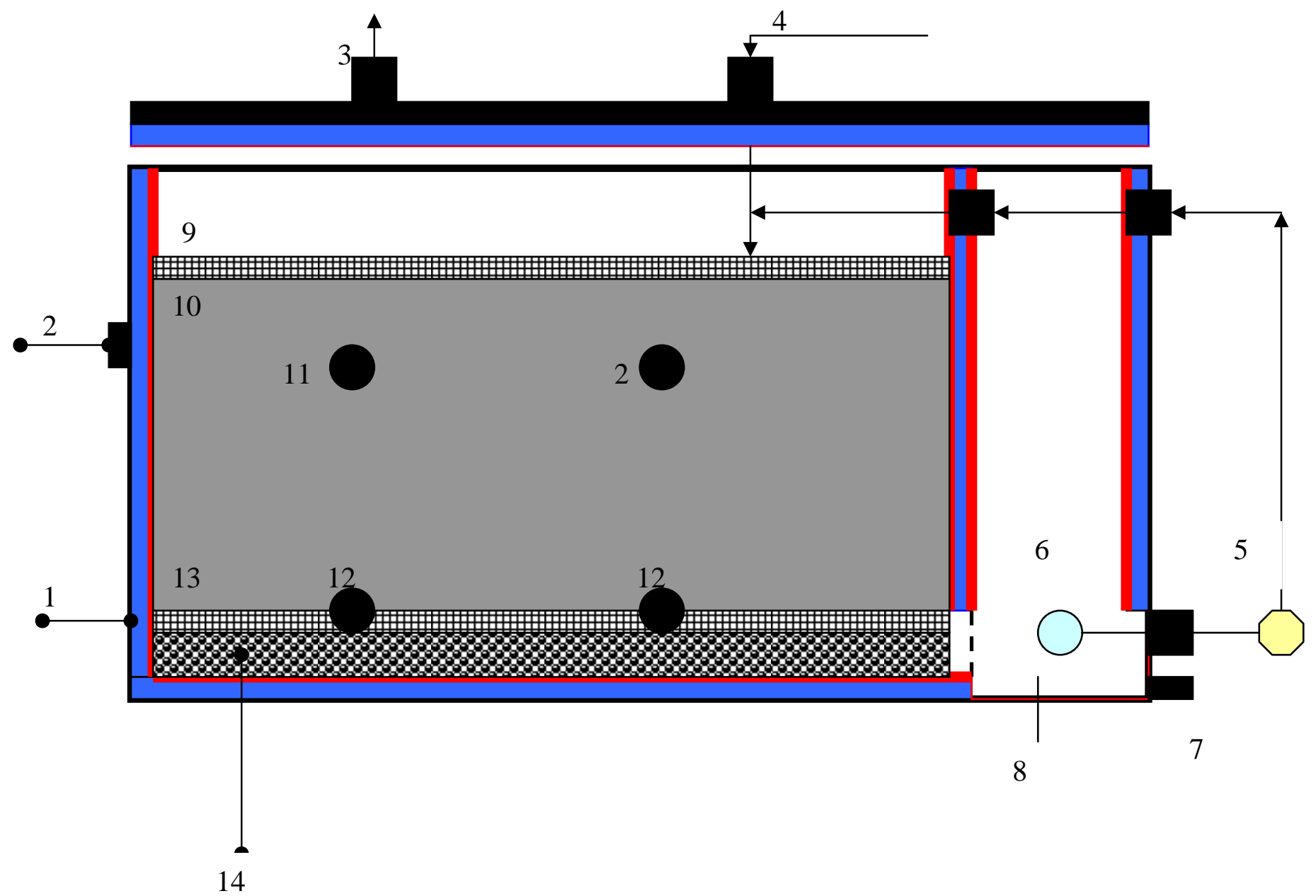


TOP VIEW:

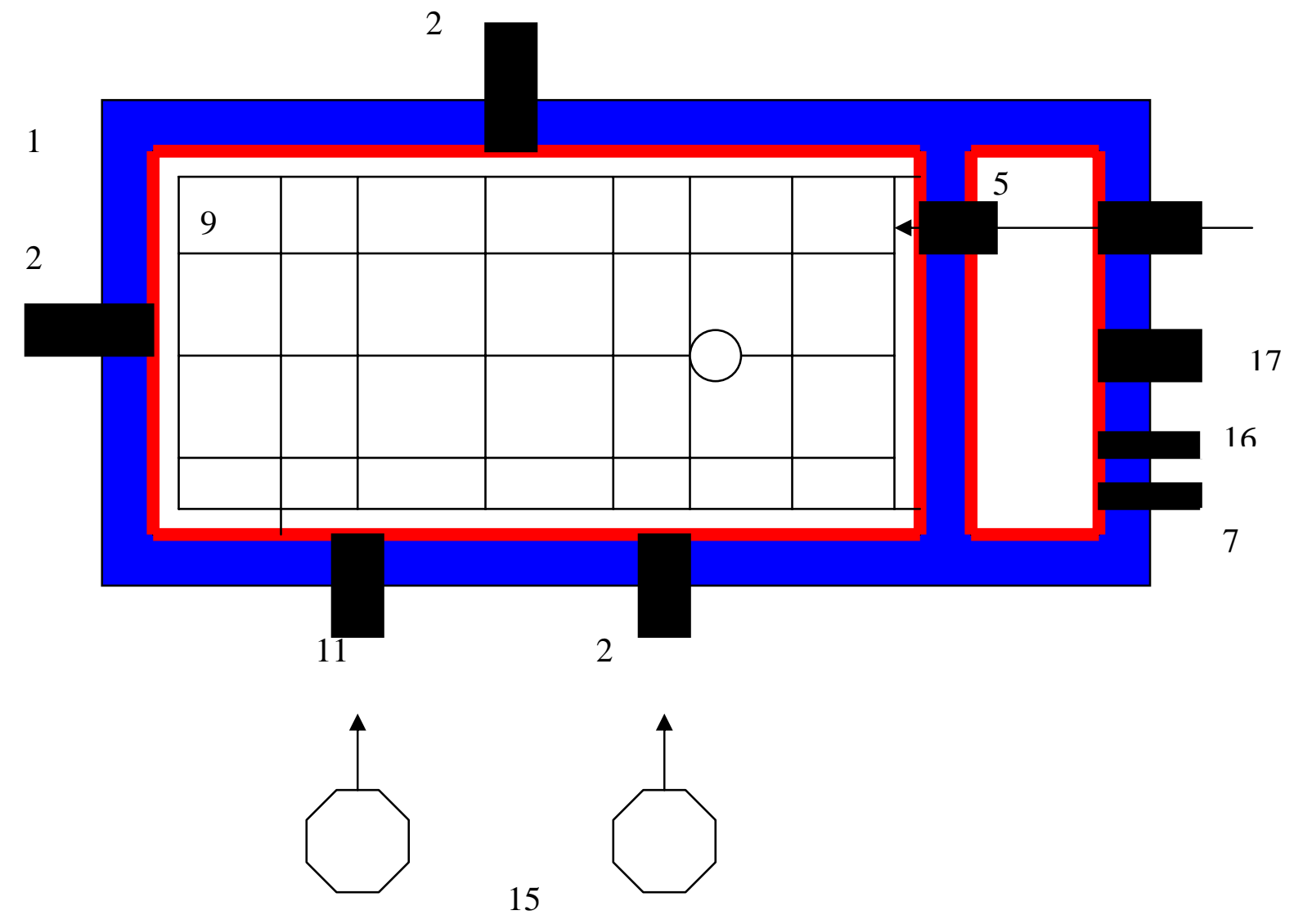




\section{LEGEND}

\section{Number Description}

1. Biocell (overall l X w X h: 28” X 13 “ X 18”, Soil holding capacity 6 gal, 304 ss 16 gage)

2. $\quad \mathrm{O} 2$ and $\mathrm{CO} 2$ sample ports

3. Vent

4. Water and nutrient inlet

5. $\quad$ Recycle pump, recycle stream

6. Water level switch

7. $\quad$ Sample/drainage port

8. Sump area

9. Sprinkler grid (perforated hoses, similar to aeration grid)

10. Soil and sand

11. Soil thermometer port

12. Aeration ports

13. Aeration grid (perforated hoses, similar to sprinkler grid)

14. Pea gravel

15. Blowers to aeration grid

$16 . \quad$ Recycle port

17. Level switch port

Color

Plastic lining (PE)

Insulation 